\title{
Structural Principles and Presidential Succession
}

Howard M. Wasserman

Florida State University, howard.wasserman@fiu.edu

Follow this and additional works at: https://ecollections.law.fiu.edu/faculty_publications

Part of the Constitutional Law Commons, Election Law Commons, Law and Politics Commons, Legislation Commons, Other Law Commons, President/Executive Department Commons, and the State and Local Government Law Commons

\section{Recommended Citation}

Howard M. Wasserman, Structural Principles and Presidential Succession, 90 Ky. L.J. 345 (2002). Available at: https://ecollections.law.fiu.edu/faculty_publications/75 


\section{HEINONLINE}

Citation: 90 Ky. L.J. 345 2001-2002

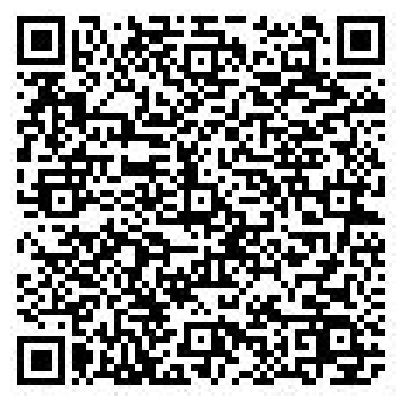

Content downloaded/printed from

HeinOnline (http://heinonline.org)

Tue Nov 11 18:09:50 2014

-- Your use of this HeinOnline PDF indicates your acceptance of HeinOnline's Terms and Conditions of the license agreement available at http://heinonline.org/HOL/License

-- The search text of this PDF is generated from uncorrected OCR text.

-- To obtain permission to use this article beyond the scope of your HeinOnline license, please use:

https://www.copyright.com/ccc/basicSearch.do?

\&operation $=$ go\&search Type $=0$

\&lastSearch $=$ simple\&all $=$ on\&titleOrStdNo=0023-026X 


\title{
Structural Principles and Presidential Succession ${ }^{*}$
}

\author{
BY HOWARD M. WASSERMAN**
}

\section{INTRODUCTION}

Tn a way it was like a bloodless coup. In March 1981, President Ronald Reagan was undergoing emergency surgery after being wounded in an assassination attempt, and Vice President George H.W. Bush was outside of Washington. Secretary of State Alexander Haig announced at a White House press briefing, "I am in control here, in the White House," suggesting that, under the Constitution, he was next in the line of succession."

Most White House officials knew Haig was wrong. ${ }^{2}$ First, and often overlooked, there was, in fact, no vacancy in the vice presidency at that time and no need for Haig, or anyone else, to assume control in the White House; the fact that Vice President Bush was not in Washington did not render him "disabled" from assuming the presidency while Reagan was undergoing surgery. Second, the issue of simultaneous vacancies, even

- Copyright $@ 2001$ Howard M. Wasserman.

"* Visiting Assistant Professor, Florida State University College of Law. J.D. 1997, B.S. 1990, Northwestern University. Thanks to Martin Redish, Steven Calabresi, Samantha Fisherman, Mark Josephson, and Matthew Umhofer for their reviews of earlier drafts. Earlier versions of this Article were presented to the faculties at Willamette University School of Law, Rutgers-Camden School of Law, Chicago-Kent College of Law, and Florida State University College of Law; my thanks for their comments and suggestions. Thanks to Jennifer, for everything else.

${ }^{1}$ See William F. Brown \& Americo R. Cinquegrana, The Realities of Presidential Succession: "The Emperor Has No Clones," 75 GEO. L.J. 1389, 1391-92 (1987); see also Richard V. Allen, The Day Reagan Was Shot, THE ATLANTIC MONTHLY, Apr. 2001, at 64-66 (discussing meetings and conversations among cabinet members and presidential aides after Reagan was shot, including Haig's assertion that he was next in the line of succession during meetings in the White House Situation Room).

${ }^{2}$ See Allen, supra note 1 , at 66. 
temporary ones, in both the presidency and the vice presidency is not controlled by the Constitution, but rather by congressional statute. ${ }^{3}$ Third, the statute, codified at 3 U.S.C. $\S 19$, actually places the Speaker of the House of Representatives next in line, followed by the President Pro Tempore of the Senate. ${ }^{4}$

The spectacle of March 1981 illustrates the tension, uncertainty, and confusion that arise with regard to many issues and questions of selection. On one hand, as Herbert Wechsler once suggested, structural and selection issues often fall by the wayside of judicial and scholarly consideration, given our focus on the power-distribution provisions of the Constitution. ${ }^{5}$ The Constitution did create and structure a government; it established three distinct and co-equal branches and prescribed the qualifications for the various offices, ${ }^{6}$ the terms, timing, and manner of selecting

${ }^{3}$ See U.S. CoNST. art. II, $§ 1$, cl. 6 ("Congress may by Law provide for the Case of Removal, Death, Resignation or Inability, both of the President and Vice President, declaring what Officer shall then act as President, and such Officer shall act accordingly, until the Disability be removed, or a President shall be elected."); 3 U.S.C. $§ 19$ (1994) (establishing order of double-vacancy succession); see also Brown \& Cinquegrana, supra note 1, at 1431-35; Americo R. Cinquegrana, Presidential Succession Under 3 U.S.C. \& 19 and the Separation of Powers: "If at First You Don't Succeed, Try, Try Again, "20 HASTINGS CoNST. L.Q. 105, 110-14 (1992).

${ }^{4}$ See 3 U.S.C. $\$ 19$ (a), (b).

${ }^{5}$ See Herbert Wechsler, The Political Safeguards of Federalism: The Role of the States in the Composition and Selection of the National Government, 54 COLUM. L. REV. 543, 543-44 (1954).

${ }^{6}$ See U.S. CONST. art. I, § 2, cl. 2 ('No Person shall be a Representative who shall not have attained to the Age of twenty five Years, and been seven Years a Citizen of the United States, and who shall not, when elected, be an Inhabitant of that State in which he shall be chosen."); id. $\S 3$, cl. 3 ('No Person shall be a Senator who shall not have attained to the Age of thirty Years, and been nine Years a Citizen of the United States, and who shall not, when elected, be an Inhabitant of that State for which he shall be chosen."); id. at art. Il, § 1, cl. 5 ("No Person except a natural born Citizen ... shall be eligible to the Office of President; neither shall any Person be eligible to that Office who shall not have attained to the Age of thirty five Years, and been fourteen Years a Resident within the United States."); id. at art. I, § 6, cl. 2 ("[N]o Person holding any Office under the United States, shall be a Member of either House during his Continuance in Office."); see also U.S. Term Limits, Inc. v. Thornton, 514 U.S. 779, 800-01 (1995) (holding that the Framers intended the Constitution to be the exclusive source of qualifications for members of Congress and that the states could not establish additional qualifications). 
officials, ${ }^{7}$ the manner of succession and filling vacancies, ${ }^{8}$ and the power of Congress to fill any structural gaps with legislation. ${ }^{9}$ On the other hand, selection issues rarely are the subjects of constitutional litigation, primarily because there can be no real legal dispute about many of these provisions-the requirements that the President be thirty-five years old, that Senators serve six-year terms, or that House members be popularly elected are clear and not open to much interpretation or dispute as to their meaning.

Selection rules and procedures may be established and detailed in the Constitution itself, as most procedures were. They also may be established pursuant to "framework legislation"--statutes passed according to ordinary

${ }^{7}$ See U.S. CoNST. art. I, $\S 2$, cl. 1 ("The House of Representatives shall be composed of Members chosen every second Year by the People of the several States...."); id. at amend. XVII, cl. 1 (providing that Senators shall be "elected by the people thereof, for six years"); id. at art. II, $\S 1$, cl. 1-2 (providing that the President shall hold office for four years and be chosen by Electors appointed by each state); id. at amend. XXII, $\S 1$ ("No person shall be elected to the office of the President more than twice. ..."); id. at art. III, $\S 1$ ("The Judges .. . shall hold their Offices during good Behaviour ..."); id. at art. I, § 4, cl. 1 ("The Times, Places and Manner of holding Elections for Senators and Representatives, shall be prescribed in each State by the Legislature thereof . . .."); see also U.S. Term Limits, 514 U.S. at 783 (striking down state law imposing term limits on members of Congress).

8 See U.S. CONST. art. I, § 2, cl. 4 ("When vacancies happen in the Representation from any State, the Executive Authority thereof shall issue Writs of Election to fill such Vacancies."); id. at amend. XVII, cl. 2 (providing that when "vacancies happen in the representation of any State in the Senate, the executive authority of such State shall issue writs of election to fill such vacancies," provided that the state executive could make temporary appointments until the vacancy could be filled by election); id. at art. II, $\S 1$, cl. 6 ("In Case of the Removal of the President from Office, or of his Death, Resignation or Inability to discharge the Powers and Duties of the said Office, the Same shall devolve on the Vice President. ..."); id. at amend. XXV, § 1 ("In case of the removal of the President from office or of his death or resignation, the Vice President shall become President.").

${ }^{9}$ See Steven G. Calabresi \& Saikrishna B. Prakash, The President's Power to Execute the Laws, 104 YALE L.J. 541, 567 (1994) (noting that some structural questions could be "punted to Congress and to future generations"); Steven G. Calabresi \& Kevin H. Rhodes, The Structural Constitution: Unitary Executive, Plural Judiciary, 105 HARV. L. REV. 1153, 1168 (1992) (stating that Congress's power to structure the executive branch derives from the Necessary and Proper Clause). 
Constitutional requirements of Bicameralism and Presentment ${ }^{10}$ that fill in the structural skeleton on those selection issues that have been left to Congress, support and implement the Constitution's structural goals, and

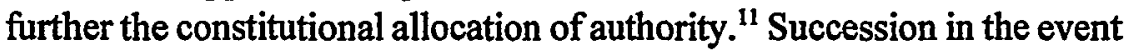
of a vacancy in both the presidency and vice presidency is one selection issue that was punted to the choices of Congress and that remains subject to change through ordinary legislative processes. ${ }^{12}$

In considering the selection of federal officials and selection procedures, we seek answers to two questions: 1) how do we select the people who will fill positions in the Federal government; and 2) why do we choose a particular selection procedure? The answer to these questions requires consideration of the Constitution's four underlying structural goals or principles, which are implicated in designing, creating, and operating a procedure for selecting government officers.

First is separation of powers, focusing on the separation and independence of each of three co-equal branches of the federal government in the execution of governing powers and in the selection of the individuals who serve in those branches. ${ }^{13}$ Second is structural federalism, focusing on the

${ }^{10}$ See U.S. CoNST. art. I, $§ 7$, cl. 2 ("Every Bill which shall have passed the House of Representatives and the Senate, shall, before it become a Law, be presented to the President of the United States."); INS v. Chadha, 462 U.S. 919, 946-51 (1983) (discussing the constitutional requirements of Bicameralism and Presentment to the President as necessary to the passage of legislation).

${ }^{11}$ See Gerhard Casper, The Constitutional Organization of the Government, 26 WM. \& MARY L. REV. 177, 187-88 (1985) (defining "framework legislation" as legislation that "attempt[s] to implement structural goals of the Constitution" and that "describes the constitutional allocation of authority and regulates the decisionmaking of the President and the Congress").

${ }^{12}$ See U.S. CoNST. art. II, $\S 1$, cl. 6 ("Congress may by Law provide for the Case of Removal, Death, Resignation or Inability, both of the President and Vice President, declaring what Officer shall then act as President, and such Officer shall act accordingly, until the Disability be removed, or a President shall be elected.").

${ }^{13}$ See THE FEDERALIST No. 51, at 289 (James Madison) (Clinton Rossiter ed., 1961); HARVEY C.MANSFIELD,JR.,AMERICA's CONSTITUTIONAL SOUL 115 (1991) ("Separation of powers is the chief of the 'auxiliary precautions' necessary against oppression by government ...."); Ann Stuart Anderson, A 1787 Perspective on Separation of Powers, in SEPARATION OF POWERS-DOES IT STILL WORK? 147 (Robert A. Goldwin \& Art Kaufman eds., 1986) ("The independence of the branches is crucial for separation of powers in the American Constitution."); Laura S. Fitzgerald, Cadenced Power: The Kinetic Constitution, 46 DUKE L.J. 679, 688 (1997) ("[T] he separation of powers principle serves mostly as a line-drawing tool to mark the boundary between one institution's constitutional tasks and those 
independent powers of the states, particularly their "rôle of great importance in the composition and selection of the central government."14 Third is democracy, meaning the role of the People as ultimate sovereign, voters, and active members of the political community, in establishing the federal government, choosing federal officials, and making political decisions. ${ }^{15}$ And the fourth principle is political partisanship, focusing on organized political parties and their role in the selection, organization, and operation of the federal government. ${ }^{16}$ Separation of powers and federalism were the

reserved to another."); Martin H. Redish \& Elizabeth J. Cisar, "If Angels Were to Govern": The Needfor Pragmatic Formalism in Separation of Powers Theory, 41 DUKE L.J. 449, 463 (1991) (arguing that separation of powers must operate "in a manner that provides each branch with the formal tools necessary to limit the excesses of its rivals" and "as a means of preventing a situation in which one branch has acquired a level of power sufficient to allow it to subvert popular sovereignty and individual liberty"); see also discussion infra notes 52-76 and accompanying text.

${ }^{14}$ Wechsler, supra note 5, at 543; see U.S. Term Limits, Inc. v. Thornton, 514 U.S. 779, 838 (1995)(Kennedy, J., concurring)("Federalism was our Nation's own discovery."); ROBERT M. HARDAWAY, THE ElECTORAL COLlEGE AND THE CONSTITUTION: THE CASE FOR PRESERVING FEDERALISM 83 (1994) (arguing that the true genius of the Constitution was the creation of a system of federalism); Wechsler, supra note 5, at 543 ("Federalism was the means and price of the formation of the Union."); see also THE FEDERALIST No. 45, at 259 (James Madison) (Clinton Rossiter ed., 1961) ("[E]ach of the principle branches of the federal government will owe its existence more or less to the favor of the State governments ....").

${ }^{15}$ See THE FEDERALIST No. 49, at 281-82 (James Madison) (Clinton Rossiter ed., 1961) (" $[T]$ he people are the only legitimate fountain of power, and it is from them that the constitutional charter, under which the several branches of government hold their power, is derived . . . ."); Wilson Carey McWilliams, Democracy and the Citizen: Community, Dignity, and the Crisis of Contemporary Politics in America, in How DEMOCRATIC IS THE CONSTITUTION? 79 (Robert A. Goldwin \& William A. Schambra eds., 1980) ("Democracy is inseparable from democratic ways of framing and arguing for political choices."); Burt Neuborne, Making the Law Safe for Democracy: A Review of "The Law of Democracy etc.," 97 MiCH. L. REv. 1578, 1592 (1999) (book review) (arguing that the "constitutional text reveals a normative vision of democracy"); see also discussion infra notes 172-243 and accompanying text.

${ }^{16}$ See Richard HofsTADTER, THE IDEA OF A PARTY System 70 (1969) (arguing that parties became a part of the machinery of government at an early point); Steven G. Calabresi, Political Parties as Mediating Institutions, 61 U. CHI. L. REv. 1479, 1530 (1994) [hereinafter Calabresi, Political Parties] (arguing that parties are effective in serving labeling and information functions to the public); 
key principles at the time of the framing of the Constitution. ${ }^{17}$ Democracy and political partisanship have increased in focus and importance as the Constitution and the federal government have progressed, both through formal constitutional amendments and through more informal, subconstitutional developments. ${ }^{18}$

Structural principles guide decisionmakers - whether the drafters of a constitutional provision, legislatures, or voters-in choosing, creating, and operating selection procedures and in selecting office holders. These principles are independent ideals with inherent value that decisionmakers should attempt to adhere to and advance in designing a selection procedure.

Larry D. Kramer, Putting the Politics Back Into the Political Safeguards of Federalism, 100 CoLuM. L. REv. 215, 267 (2000) (describing political parties as one mediating institution helping to manage modern politics); Michael J. Malbin, Political Parties Across the Separation of Powers, in AMERICAN POLITICAL PARTIES AND ConstituTIONAL Politics 75 (Peter W. Schramm \& Bradford P. Wilson eds., 1993) (arguing that parties work across branches and bring coordination to the branches); Harvey C. Mansfield, Jr., Political Parties and American Constitutionalism, in AMERICAN POLITICAL PARTIES AND CONSTITUTIONAL POLITICS, supra, at 1 (arguing that parties, not mentioned in the Constitution, organize by combining branches and functions); see also discussion infra notes 93-155 and accompanying text.

${ }^{17}$ See Vikram David Amar, Indirect Effects of Direct Election: A Structural Examination of the Seventeenth Amendment, 49 VAND. L. REV. 1347, 1350 (1996) [hereinafter V. Amar, Indirect Effects] (describing federalism and separation of powers as the two great themes of the constitutional design); see also HARDAWAY, supra note 14, at 13 (arguing that separation of powers was at the "heart of the constitutional fabric"); $i d$. at 14 (discussing the framers' need to protect states in designing a scheme of presidential selection); HOFSTADTER, supra note 16, at 52 (arguing that the framers relied on the "classic doctrine of the separation of powers").

${ }^{18}$ See Walter Berns, Does the Constitution "Secure These Rights"?, in How DEMOCRATIC IS THE CONSTITUTION?, supra note 15, at 59 ("The Constitution is more democratic today than in the past and promising (or threatening) to become still more democratic."); Mansfield, supra note 16, at 14-15 (describing the "longterm, uninterrupted trend toward democratization" and the fact that this has been led by "parties and by their great leaders in the critical elections"); McWilliams, supra note 15, at 79 ("Most Americans would agree that the Constitution has become more democratic with time."); Abner J. Mikva, Doubting Our Claims to Democracy, 39 ARIZ. L. REV. 793, 797 (1997) ("We have progressed from those undemocratic beginnings."); Peter M. Shane, Disappearing Democracy: How Bush v. Gore Undermined the Federal Right to Vote for Presidential Electors, 29 FLA. ST. U. L. REV. 535, 548 (2001) (describing "the plain democratic trajectory of constitutional development since 1868"). 
The principles are not necessarily coextensive with the Constitution. That is, a particular selection procedure may be inconsistent with one or more structural principles without necessarily being inconsistent with the text of the Constitution.

Structural principles help explain selection decisions. The creation and application of a selection procedure reflects a choice or emphasis on some principle or principles over others. Choices as to which principle to emphasize can and will change over time, and a change in emphasis will require and produce a different or amended selection method. For example, the move from legislative selection to direct popular election of United States Senators in the Seventeenth Amendment reflected an obvious emphasis on democracy and a decision to advance democracy over federalism. ${ }^{19}$

Every selection decision can and should be examined against these principles to determine what principle or principles are at work, whether the chosen procedure properly reflects these principles, and whether a different selection procedure would better serve the desired principles. Structural principles must be considered individually and in an overall balance. A particular selection procedure might emphasize one principle, but at the same time be so inconsistent with others as to be problematic.

The double-vacancy succession statute illustrates the use and operation of structural principles in designing and applying framework legislation. The current version of $\S 19$ provides for succession by the Speaker of the House, then President Pro Tempore of the Senate, then cabinet officers, beginning with the Secretary of State and proceeding according to the age of each department. ${ }^{20}$ The statute was passed in 1947 and was the third attempt to establish a double-vacancy succession order. ${ }^{21}$ The new version was passed at the urging of President Harry S. Truman, who explicitly

${ }^{19}$ See U.S. CONST. amend. XVII, cl. 1 ("The Senate of the United States shall be composed of two Senators from each State, elected by the people thereof....") amending U.S. CONST. art. I, § 3, cl. 1 ("The Senate of the United States shall be composed of two Senators from each State, chosen by the Legislature thereof ...."); see also Jay S. Bybee, Ulysses at the Mast: Democracy, Federalism, and the Siren' Song of the Seventeenth Amendment, 91 NW. U. L. REV. 500, 538 (1997) ("[T] he people ... simply preferred democracy to representation and were willing to shoulder the loss to constitutional federalism.").

${ }^{20}$ See 3 U.S.C. $\$ 19$ (1994).

${ }^{21}$ See Akhil Reed Amar \& Vikram David Amar, Is the Presidential Succession Law Constitutional?, 48 STAN. L. REV. 113, 132-35 (1995) [hereinafter Amar \& Amar, Succession]; Cinquegrana, supra note 3, at 110-11; see also discussion infra notes $29-32$ and accompanying text. 
emphasized the democratic principle and his view that the presidency should be filled by a member of Congress, who has stood for popular election at some level, rather than by an unelected cabinet officer. ${ }^{22}$ Truman also believed that Speaker succession made it more likely that the same party would retain control of the executive branch, because the Speaker and President often would be in party agreement. ${ }^{23}$

But a closer examination of the statute shows that 1) it actually is not the best way to emphasize and serve the democratic principle and 2) it is entirely inconsistent with the separation of powers and political partisanship principles to a degree that cannot otherwise be remedied without changing the statute.

There has been renewed interest in double-vacancy succession in the wake of September 11, given evidence that the terrorist attack may have been intended to reach both the President on board Air Force One and the Vice President in the White House-events which could have triggered $\S$ 19. This new interest provides an appropriate moment to review the statute and to ensure the creation of the best succession scheme. It compels us to examine and consider the inconsistencies between $\S 19$ and these structural principles and to establish a succession scheme that is most consistent with the principles underlying constitutional selection issues. Such a scheme should include only cabinet officers at the top of the line of succession and should provide for a special election to choose a new President and Vice President within approximately one year of the event that triggers the statute.

This Article will examine the nature, details, origins, and evolution of three structural principles-separation of powers, political partisanship, and democracy - and the role each plays under the Constitution, particularly with regard to selection of the President and the executive branch. It then will consider $\S 19$ in light of each principle and examine how consistent the statute is with each. Ultimately, it concludes that the current succession order is not consistent with these three principles, either individually or in an overall balance. It would be more consistent to amend the statute again and to establish succession by cabinet officers, with a provision for a special election to choose a new President and Vice President. ${ }^{24}$

${ }^{22}$ See Harry S. Truman, Special Message to the Congress on the Succession to the Presidency, PUB. PAPERS 124 (June 19, 1945); Brown \& Cinquegrana, supra note 1, at 1421-22 \& n.111; see also discussion infra notes $42-47$ and accompanying text.

${ }^{23}$ See Truman, supra note 22, at 129.

${ }^{24}$ See discussion infra notes $268-82$ and accompanying text. 


\section{STATUTORY HISTORY AND PROVISIONS}

Under Article II, Section 1, Clause 6 of the Constitution, as affirmed by the Twenty-Fifth Amendment, if there is a vacancy in the presidency, the Vice President becomes President. ${ }^{25}$ The Constitution grants Congress the power to provide by law for vacancies in both offices, "declaring what Officer shall then act as President, and such Officer shall act accordingly, until the Disability be removed, or a President shall be elected."26

Two points of this provision are notable. First, anyone who succeeds under such a statute does not become President, only acting president. The difference is largely semantic, as it appears that the acting president exercises the executive power under the Constitution, just as the President would. This is a product of both the plain language of the Constitution and the general separation of powers prohibition on Congress selecting the President. ${ }^{27}$ Second, the provision specifically refers to "officers" acting as President; whatever the scope of that term, clearly Congress could not designate any random private person or anyone outside the federal government as the acting president. ${ }^{28}$

Congress has exercised its Constitutional power to legislate for vacancies in both offices on three occasions. The first statute was passed in 1792, establishing succession by the President Pro Tempore of the Senate and then the Speaker of the House, with a provision for a special election to be called by the Secretary of State within thirty-four days to choose a President and Vice President. ${ }^{29}$ In 1886 , the statute was amended

${ }^{25}$ See U.S. CONST. art. II, $\S 1$, cl. 6 ("In Case of the Removal of the President from Office, or of his Death, Resignation, or Inability to discharge the Powers and Duties of the said Office, the Same shall devolve on the Vice President ....."); id. at amend. XXV, $\S 1$ ("In case of the removal of the President from office or of his death or resignation, the Vice President shall become President.").

${ }^{26}$ Id. at art. II, $\S 1$, cl. 6.

${ }^{27}$ See Brown \& Cinquegrana, supra note 1, at 1436 (stating that a $§ 19$ successor becomes acting president because the Constitution does not authorize Congress to use its legislative powers to create a new President); see also HARDAWAY, supra note 14, at 13 (discussing the rejection of congressional selection at the Founding).

${ }^{28}$ See Amar \& Amar, Succession, supra note 21, at 120 ("Congress can designate only officers, not private citizens, to act as President ...."').

${ }^{29}$ See id at 132-33; Akhil Reed Amar, Presidents Without Mandates (With Special Emphasis on Ohio), 67 U. CIN. L. REV. 375, 384-85 (1999) [hereinafter A. Amar, Mandates]; Brown \& Cinquegrana, supra note 1, at 1418; Cinquegrana, supra note 3, at 110 . 
to provide for cabinet succession, beginning with the Secretary of State. ${ }^{30}$ This change was brought about in part by concerns for the long stretches in which the offices of Speaker and President Pro Tem were vacant during the previous century, as well as concerns for the conflicts of interest that arose under the original statute. ${ }^{31}$

In 1947, Congress amended the statute to its current version, codified at 3 U.S.C. $\$ 19$. The amended law provides for succession by the Speaker and then the President Pro Tem, followed by cabinet officers, beginning with the Secretary of State and proceeding according to the age of the department. $^{32}$

Anyone who succeeds under $\S 19$ must resign her prior office. ${ }^{33}$ This is a constitutional requirement for the Speaker and President Pro Tem pursuant to the Incompatibility Clause, which prohibits members of Congress from serving in the executive branch. ${ }^{34}$ It is not a requirement for

${ }^{30}$ See Amar \& Amar, Succession, supra note 21, at 133-34; A. Amar, Mandates, supra note 29, at 386; Brown \& Cinquegrana, supra note 1, at 1419-20 \& n.109; Cinquegrana, supra note 3, at 110.

${ }^{31}$ See Amar \& Amar, Succession, supra note 21, at 134; Brown \& Cinquegrana, supra note 1, at 1419-20; see also discussion infra notes 78-81 and accompanying text.

${ }^{32}$ See 3 U.S.C. § 19(a), (b) (1994); id. § 19(d)(1)(establishing succession order of Secretary of State, Secretary of the Treasury, Secretary of Defense, Attorney General, Secretary of the Interior, Secretary of Agriculture, Secretary of Commerce, Secretary ofLabor, Secretary of Health and Human Services, Secretary of Housing and Urban Development, Secretary of Transportation, Secretary of Energy, Secretary of Education, Secretary of Veterans Affairs); see also Amar \& Amar, Succession, supra note 21, at 134-35; A. Amar, Mandates, supra note 29, at 386; Brown \& Cinquegrana, supra note 1, at 1431-33; Cinquegrana, supra note 3 , at $111-13$.

${ }^{33}$ See 3 U.S.C. § 19(a)(1), (b), (d)(3); Amar \& Amar, Succession, supra note 21 , at 135 (criticizing the requirement that a cabinet officer be made to resign her post in order to act as president, because such officer would be out of a job when the temporary disability was removed); Brown \& Cinquegrana, supra note 1, at 1437 (describing the problem that anyone who resigned to act as President during a temporary vacancy would be out of a job altogether when the President returned).

${ }^{34} \mathrm{See}$ U.S. CONST. art. $1, \S 6, \mathrm{cl} .2$ ("[N] 0 Person holding any Office under the United States shall be a Member of either House during his Continuance in Office."); Steven G. Calabresi \& Joan L. Larsen, One Person, One Office: Separation of Powers or Separation of Personnel?, 79 CORNELL L. REV. 1045, $1047,1048-49$ (1994) (discussing the importance to separation of powers of this clause); see also discussion supra notes 75-76 and accompanying text. 
cabinet officers: a President is not constitutionally barred from serving as her own cabinet secretary. Either legislative officer may decline to become acting president - by not resigning her legislative office and seat, thereby leaving herself constitutionally disabled from serving in the executive branch-and may allow the executive power to devolve to the cabinet. $^{35}$

However, a cabinet officer serves as acting president only until a "prior-entitled individual is able to act," which statutory term includes the Speaker and President Pro Tem. ${ }^{36}$ By resigning the speakership and her House seat, the Speaker removes her "disability" from being acting president and becomes a constitutionally qualified prior-entitled individual who now may supplant the cabinet officer as acting president. ${ }^{37}$ This may happen at any time and for any reason, for the duration of the presidential term, by anyone occupying the speakership or presidency pro tempore, including someone who initially had declined to assume the executive power. $^{38}$

Finally, the current statute does not provide for a special election; assuming no supplantation and permanent vacancies in both the presidency and the vice presidency, the acting president will serve until the next

New Jersey provides a good contrast. The state constitution provides that, in the event of a vacancy in the office of Governor, the President of the Senate is to assume the powers of Governor "for the time being," with no requirement that she

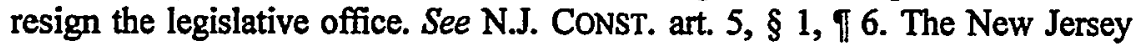
Constitution does not contain an equivalent of the Incompatibility Clause. When New Jersey Governor Christine Todd Whitman was appointed to head the Environmental Protection Agency in 2001, Senate President Donald DiFrancesco became acting governor, while retaining his Senate seat and his position as Senate President.

${ }^{35}$ See 3 U.S.C. § 19(a)(1), (b); see also Cinquegrana, supra note 3, at 114.

${ }^{36}$ See 3 U.S.C. § 19(d)(2); see also Amar \& Amar, Succession, supra note 21, at 135; Brown \& Cinquegrana, supra note 1, at 1437-38; Cinquegrana, supra note 3, at 114-15.

${ }^{37}$ See Brown \& Cinquegrana, supra note 1, at 1437-38.

${ }^{38}$ See Cinquegrana, supra note 3 , at 115 (arguing that "prior-entitled individual" would include anyone who subsequently became Speaker or President Pro Tem, even if the prior holder of that office had declined to become acting President); see also Amar \& Amar, Succession, supra note 21, at 135 (arguing that the supplantation provision violates the Constitution because the Succession Clause gives Congress the power to designate an acting president who shall act until the presidential disability be removed or a new President elected but does not permit Congress to declare that an officer shall act "until some other suitor wants the job"). 
quadrennial presidential election. ${ }^{39}$ This is true whether six months or three and a half years remain on the current presidential term. This lack of temporal limitation requires that the acting president be accorded the same independence from Congress and the same vitality in executive action as would a duly elected President, given the possibility that she will serve a significant amount of time. ${ }^{40}$ The lack of temporal limitation also raises concerns that someone not elected to the presidency will occupy the White House for a substantial period of time. ${ }^{41}$

President Harry Truman first proposed a new succession statute in a 1945 message to Congress, suggesting that the law be amended to substitute legislative succession for the then-existing cabinet succession. Truman, who had succeeded to the presidency following the death of President Franklin Roosevelt and served his first term without a Vice President, ${ }^{42}$ sent the message when he nominated George Marshall to be Secretary of State. Truman realized that, under the law in place at the time, he was appointing his immediate potential successor, the person who would succeed to the presidency were Truman unable to complete his term. Truman did not "believe that in a democracy this power should rest with the Chief Executive. $\$ \$ 43$

Several points in Truman's message are worth emphasizing. First, Truman argued:

In so far as possible, the office of the President should be filled by an elective officer. There is no officer in our system of government, besides the President and Vice President, who has been elected by all the voters of the country.

${ }^{39}$ See 3 U.S.C. $\$ 19$ (c)(2) ("An individual acting as president ... shall continue to act until the expiration of the then current Presidential term, except that ... if his discharge of the powers and duties of the office is founded in whole or in part on the inability of the President or Vice President, then he shall act only until the removal of the disability of one of such individuals."); $i d . \S 19(\mathrm{~d})(2)$ (same as to cabinet officers); see also Amar \& Amar, Succession, supra note 21, at 134-35; Brown \& Cinquegrana, supra note 1, at 1436; Cinquegrana, supra note 3 , at 11314.

${ }^{40}$ See discussion supra notes 67-68 and accompanying text.

${ }^{41}$ See discussion supra notes 268-69 and accompanying text.

${ }^{42}$ Prior to passage of the Twenty-Fifth Amendment in 1967, the Constitution did not provide a mechanism for appointing a new Vice President when the Vice President had ascended to the presidency or when the vice presidency had become vacant; the office remained vacant until the next regular presidential election.

${ }^{43}$ See Truman, supra note 22, at 129. 
The Speaker of the House of Representatives, who is elected in his own district, is also elected to be the presiding officer of the House by a vote of all the Representatives of all the people of the country. As a result, I believe that the Speaker is the official in the Federal Government, whose selection next to that of the President and Vice President, can be most accurately said to stem from the people themselves. ${ }^{44}$

Second, he compared the Senate and House:

[M]embers of the Senate are not as closely tied in by the elective process to the people as are Members of the House of Representatives. A completely new House is elected every two years, and always at the same time as the President and Vice President. Usually it is in agreement politically with the Chief Executive. Only one-third of the Senate, however, is elected with the President and Vice President. The Senate might, therefore, have a majority hostile to the policies of the President, and might conceivably fill the Presidential office with one not in sympathy with the will of the majority of the people. ${ }^{45}$

Third, Truman suggested that there should be a "special election called for the purpose of electing a new President and Vice President."36 The President elected at this special election would fill only the remainder of the term of the deceased or disabled President and Vice President; a President then would be elected during the next regularly scheduled quadrennial election. ${ }^{47}$ This last point did not make it into the final statute.

\section{SUCCESSION STATUTE AND STRUCTURAL PRINCIPLES}

We now consider the nature, history, and development of three principles - separation of powers, political partisanship, and democracy ${ }^{48}$-and

${ }^{44} I d$.

${ }^{45}$ Id. at $129-30$.

${ }^{46} \mathrm{Id}$. at 130.

${ }^{47}$ See id.

48 Federalism has dropped out of the equation on this particular framework legislation. The power to designate who shall act as President was left to Congress, not to the states, and the term "officers" in the Constitution certainly cannot be read to include state officials.

In the aftermath of September 11, some have proffered the danger of a massive terrorist attack killing the President, Vice President, and everyone else in the possible line of statutory succession, arguing for extending the line of statutory 
how they particularly affect selection of the President and the executive branch. We examine how consistent the current succession statute is with each of these principles, considered individually and in an overall balance.

The inconsistency of $\S 19$ with these principles does not necessarily render the statute unconstitutional. Akhil and Vik Amar have made that argument, however, suggesting that legislative succession is not permitted under the plain language of the Constitution. They argue that the Constitution refers to "officers," which means "Officers of the United States," which means only executive branch officers, not legislative branch officers. ${ }^{49}$ In their view, the most straightforward reading of the Constitution's text, the clear implication of five related yet distinct structural considerations (including separation of powers), and the spirit of twentieth century developments "all point to the same conclusion: Legislators are not 'Officers' under the Succession Clause."so

succession to include state governors, in order to designate a new President and to ensure the continued existence of the federal government. It is questionable whether such a mass annihilation of the federal government is any more likely from a terrorist attack now than it was from a Soviet nuclear attack during the Cold War. Indeed, it arguably would have been easier to wipe out the entire federal government with a large-scale nuclear first strike than with a coordinated series of multiple individual terrorist attacks. Moreover, one Cabinet member always remains behind when the President addresses a joint session of Congress, the one time when all of the upper levels of the federal government are in the same place.

The proposed change to the statute would require consideration of the federalism principle. We do note that adding governors to the line of succession would first require an amendment to Article II, Section 1, Clause 6, to remove or change the word "officer," which, regardless of its precise scope, does not include governors or other state officials, who are not officers under the law, authority, or government of the United States. See Amar \& Amar, Succession, supra note 21, at 114-17 (discussing several uses of the word "officer" throughout the Constitution, all of which specifically reference the United States as the source of authority for that officer).

In any event, such a change is a separate issue and beyond the scope of this Article, as it focuses on the lower end of succession and how far down the line should extend in order to account for every eventuality. Our focus is on the top of succession and the question of who should be the first officer in line to become acting president in the event of a double vacancy.

${ }^{49}$ See Amar \& Amar, Succession, supra note 21, at 115-16 (arguing that federal legislators are not "Officers under the United States" or "Officers of the United States").

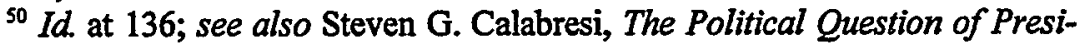
dential Succession, 48 STAN. L. REV. 155, 156 (1995) [hereinafter Calabresi, Presidential Succession] (agreeing with the Amars' conclusion, but arguing that the 
This Article proceeds from the assumption that $\S 19$ is constitutional, that the Constitution gives Congress broad discretion in designing this particular piece of framework legislation, and that Congress could designate a legislative branch officer to become acting president, if it chose to do so. Our analysis uses structural principles as guides to the exercise of that discretion, apart from the question of constitutionality. The question is not what Congress could do as a matter of power but what it should do as a matter of structural policy.

Our focus is on what is the best succession scheme, as a normative matter. These three principles show that, regardless of what Congress could do under the Constitution, it should replace the current statute with one that provides for succession only by cabinet officers, with a special election to choose a new President and Vice President to serve the remainder of the unexpired four-year term. ${ }^{51}$ This would be more consistent with separation of powers, political partisanship, and democracy, considered individually and in an overall balance.

\section{A. Separation of Powers}

\section{Separation of Powers Considered}

Separation of powers was intended to be the Constitution's primary structural principle. ${ }^{52}$ To the Framers, accumulation of all power in a small number of hands was, in Madison's words, "the very definition of tyranny." 353 Power was to be divided among three coordinate branches of the federal government; each branch was to have its own realm of power and was to be provided with the formal tools, means, and will necessary to

issue of constitutionality is a political question that is not subject to judicial review); John F. Manning, Not Proved: Some Lingering Questions About Legislative Succession to the Presidency, 48 STAN. L. REV. 141, 142 (1995) (suggesting reasons to hesitate before firmly declaring the current succession order unconstitutional).

${ }^{51}$ See Calabresi, Presidential Succession, supra note 50, at 156; see also discussion infra notes 268-82 and accompanying text.

${ }^{52}$ See HARDAWAY, supra note 14, at 13 (describing separation of powers as the "heart of the constitutional fabric"); HOFSTADTER, supra note 16, at 52 (arguing that systemic protections in the Constitution were to be provided by the "classic doctrine of separation of powers").

53 THE FEDERALIST No. 47, at 269 (James Madison) (Clinton Rossiter ed., 1961). 
protect that realm. ${ }^{54}$ The result is a system in which the accumulation of all power in the same or a limited number of hands would be difficult or impossible, but also one in which the diffusion of power makes sudden, rapid, or dramatic policy action difficult and unlikely. ${ }^{55}$

The Framers particularly recognized the need for separation in selection and in the procedures for selecting people to serve in the various departments in the federal government. As Madison wrote:

[E]ach department should have a will of its own; and consequently should be so constituted that the members of each should have as little agency as possible in the appointment of the members of the others. ${ }^{56}$

Each department represents separate, independent, and distinct constituencies, and the members of each constituency are responsible for the

${ }^{54}$ See Redish \& Cisar, supra note 13, at 463 (arguing that separation of powers must operate "in a manner that provides each branch with the formal tools necessary to limit the excesses of its rivals" and "as a means of preventing a situation in which one branch has acquired a level of power sufficient to allow it to subvert popular sovereignty and individual liberty"); see also MANSFIELD, supra note 13, at 115 ('Separation of powers is the chief of the 'auxiliary precautions' necessary against oppression by government ...."); Anderson, supra note 13, at 147 ("The independence of the branches is crucial for separation of powers in the American Constitution."); Fitzgerald, supra note 13, at 686 ("[T] powers principle serves mostly as a line-drawing tool to mark the boundary between one institution's constitutional tasks and those reserved to another.").

${ }^{55}$ See Calabresi \& Larsen, supra note 34, at 1047 (arguing that separation of powers was one way the Framers sought to make it "hard for government to act"); James W. Ceaser, In Defense of Separation of Powers, in SEPARATION OF POWERS-DOES IT STILL WORK?, supra note 13, at 180 (discussing the need to use political power with energy and discretion at critical moments, which separation of powers restricts); Lloyd N. Cutler, To Form a Government, in SEPARATION OF POWERS-DOES IT STILL WORK?, supra note 13, at 2 [hereinafter Cutler, To Form a Government] (arguing that separation of powers "has become a structure that almost guarantees stalemate today"); Richard A. Epstein, In Praise of Divided Government, 68 WASH. U.L.Q. 567, 571 (1990) (arguing that separation of power is "a way to slow down the political juggernaut."); James Q. Wilson, Political Parties and the Separation of Powers, in SEPARATIONOF POWERS-DOESIT STILL WORK?, supra note 13, at 18 (arguing that the chief criticism of the separation of powers is that it inhibits the capacity of the government "to enact policies that are bold, timely, and comprehensive").

${ }^{56}$ ThE FEDERAlist No. 51, at 289 (James Madison) (Clinton Rossiter ed., 1961). 
appointment of that branch of the government. ${ }^{57}$ The House is closest to the People, and its members are popularly elected by the smallest group of voters. ${ }^{58}$ The Senate is closest to the states as states; as originally designed its members were selected by the legislatures of the several states, and with direct election Senators still represent a single state's broad and more diverse constituency. ${ }^{59}$ The President is chosen by a compound of all of these constituencies, reflecting the nation as a whole or, more specifically and accurately, reflecting a broad coalition of state constituencies. ${ }^{60}$ The

${ }^{57}$ See Calabresi \& Larsen, supra note 34, at 1093 (arguing that the Constitution creates "three different and independent electoral constituencies"); Fitzgerald, supra note 13, at 750 (arguing that each of the three branches are different manifestations of the same authority, "speaking with different voices and through different 'channels" "); Charles M. Hardin, The Separation of Powers Needs Major Revision, in SEPARATIONOF POWERS-DOES IT STILL WORK?, supra note 13, at 90 ("[T]he president and the Congress have somewhat different constituencies....").

${ }^{58}$ See THE FEDERALIST No. 39, at 212 (James Madison) (Clinton Rossiter ed., 1961) ("The House of Representatives will derive its powers from the people of America . . . ."); see also Amar \& Amar, Succession, supra note 21, at 130 (discussing the "narrow, local strategies by which Congressmen secure election in their states and districts, with promises of pork and parks"); Calabresi \& Larsen, supra note 34, at 1093; Fitzgerald, supra note 13, at 748 ("The citizen within her House constituency thus may identify herself and her political priorities primarily on the basis of local concerns."); Wechsler, supra note 5, at 552 (emphasizing the localism and separatism of Congress).

${ }^{59}$ See THE FEDERALIST No. 39, at 212 (James Madison) (Clinton Rossiter ed., 1961) ("The Senate, on the other hand, will derive its powers from the States as political and coequal societies ...."); see also Calabresi, Political Parties, supra note 16, at 1507 ("Senators represent states ...."); Calabresi \& Larsen, supra note 34, at 1093 (describing each Senator's constituency of a single state); Fitzgerald, supra note 13, at 749 (" $[\mathrm{A}]$ Senate constituency may take on the more polyglot character of the state as a whole.").

${ }^{60}$ See THE FEDERALIST No. 39, at 212 (James Madison) (Clinton Rossiter ed., 1961) ("The executive power will be derived from a very compound source."); id. (describing the method of selecting the President and its many components); see also Steven G. Calabresi, Some Normative Arguments for the Unitary Executive, 48 ARK. L. REV. 23, 59 (1995) [hereinafter Calabresi, Some Normative Arguments] ("[T] he President is unique in our constitutional system as being the only official who is accountable to a national voting electorate and no one else."); Calabresi, Political Parties, supra note 16, at 1508 ("The President is electorally responsible to the nation as a whole."); Calabresi \& Larsen, supra note 34, at 1093 (describing the President's and Vice President's national constituency); Fitzgerald, supra note 13, at 754 (emphasizing the President's political identification with and dependence on a national constituency containing elements of, but independent of, 
President is to be independent not only of Congress for her appointment, but also independent of the individual smaller constituencies represented in Congress. ${ }^{61}$

To the extent such clear divisions in selection are impossible or inexpedient, other protections maintain the necessary separation and independence of the branches. ${ }^{62}$ Madison specifically cited the obvious example of the federal judiciary: Judges are nominated by the President and confirmed by the Senate, but once appointed, the protections of life tenure and guaranteed salary "soon destroy all sense of dependence" on the appointing branches. ${ }^{63}$

Similarly, the Senate's substantial role in confirming high-level executive branch officers, such as cabinet secretaries, was seen as an important check on the appointment of unfit characters and a way to ensure some care on the part of the President in making her selections. ${ }^{64}$ However, the choice of executive branch officers ultimately remains with the President. ${ }^{65}$ Moreover, once confirmed, cabinet officers generally serve under the exclusive policy control and at the pleasure of the President. ${ }^{66}$

smaller constituencies).

${ }^{61}$ See Fitzgerald, supra note 13, at 754-55 ("Article Il's electoral college makes the President politically dependent on a national People and therefore relatively independent not only of the Congress institutionally, but of the particular constituencies already represented in its two houses.").

${ }^{62}$ See THE FEDERALIST No. 51, at 289 (James Madison) (Clinton Rossiter ed., 1961) (stating that some deviations from strict separation must be admitted).

${ }^{63}$ See id; see also U.S. CoNST. art. III, § 1 ("The Judges . . . shall hold their Offices during good Behaviour, and shall ... receive for their Services, a Compensation, which shall not be diminished during their Continuance in Office.").

${ }^{64}$ See U.S. CONST. art. II, $\S 2$, cl. 2 (describing Senate role in providing "Advice and Consent" to President's nomination of ambassadors, public ministers and consuls, judges, and other officers of the United States); THE FEDERALIST NO. 76, at 425 (Alexander Hamilton) (Clinton Rossiter ed., 1961); see also STEPHEN L. CARTER, THE CONFIRMATION MESS 12 (1994) (discussing initial concerns with the constitutional plan for executive appointments and the fact that the constitutional scheme has caused "no end of trouble").

${ }^{65}$ See THE FEDERALIST No. 65, at 364 (Alexander Hamilton) (Clinton Rossiter ed., 1961) (stating that the executive is to be the principal agent in the appointment process); see also CARTER, supra note 64, at 15 ("What makes our confirmation process messy, however, is our inability to reach any sort of consensus on what 'close scrutiny' involves.").

${ }^{66}$ See Calabresi \& Rhodes, supra note 9, at 1168 (arguing that the President must maintain the constitutional power to control his subordinates); Gary Lawson, The Rise and Rise of the Administrative State, 107 HARV. L. REV. 1231, 1242-43 
Congressional influence is limited to removal through the laborious impeachment process (unlikely), control over agency and department funding, and the congressional oversight process, in which committees monitor, question, and challenge the actions of cabinet officers.

It was with this understanding of separation of powers that the Framers specifically considered and rejected legislative selection of the President. The Framers feared that an executive so chosen would be too beholden and dependent on the legislature to exercise any real power or discretion, incapable of initiative, and motivated more by a desire to please Congress in order to gain reelection than by a desire to exercise independent judgment in acting for the public good. ${ }^{67}$ The tendency in a republican government, Madison suggested, was the aggrandizement of the legislative branch; ${ }^{68}$ a substantial legislative role in the selection of the executive would further enable such aggrandizement. Members of Congress are prohibited even from serving as individual presidential electors and directly choosing the President. ${ }^{69}$ Moreover, Congress may remove the President only through the cumbersome impeachment process. ${ }^{70}$

(1994) (discussing the President's power to control his subordinates in the executive branch).

${ }^{67}$ See HARDAWAY, supra note 14, at 13 (discussing arguments against legislative selection and the fear of an executive "beholden" to Congress and "under the influence of an improper obligation" to Congress); TADAHISA KURODA, THE ORIGINS OF THE TWELFTH AMENDMENT 8 (1994) (discussing fear of executive becoming too "dependent on legislators, incapable of initiative, and worried about pleasing them in order to gain reelection"); Anderson, supra note 13, at 147 ("The delegates agreed generally that an executive chosen by the legislature was not independent."); Cinquegrana, supra note 3, at 123 (discussing Gouverneur Morris's argument that an executive chosen by the national legislature could not be independent of it, leading to legislative usurpation of executive power); Hardin, supra note 57 , at 90 (" $[\mathrm{N}]$ either the presidentnor the Congress exercises significant influence on the nomination of the other."); William Josephson \& Beverly J. Ross, Repairing the Electoral College, 22 J. LEGIS. 145, 152 (1996)(discussing Morris's arguments). 1961).

${ }^{68}$ See THE FEDERALIST No. 48, at 277 (James Madison) (Clinton Rossiter ed.,

${ }^{69}$ See U.S. CoNST. art. II, § 1, cl. 2 (" $[\mathrm{N}] \mathrm{o}$ Senator or Representative . . . shall be appointed an Elector.").

${ }^{70}$ See id. $\S 4$ ("The President, Vice President and all civil Officers of the United States, shall be removed from Office on Impeachment for, and Conviction of, Treason, Bribery, or other high Crimes and Misdemeanors."); see also Cinquegrana, supra note 3, at 129 (stating that the Framers abhorred "any process that would cleave the fine lines of separated powers they crafted and create a chief 
The legislature plays a substantial role in selecting the executive only if no candidate captures a majority in the Electoral College, in which case the House chooses the President (and the Senate chooses the Vice President) from among the top electoral vote-getters. ${ }^{71}$ Some Framers believed that a single candidate rarely could achieve sufficient nationwide support to gain an electoral majority, resulting in all or most presidential elections being thrown to the House of Representatives, with the Electoral College functioning largely as a nominating body. ${ }^{72}$ Even in a contingency election, Congress is not entirely free in choosing the executive but is limited to voting for the candidates nominated by the Electoral College process. ${ }^{73}$ Congress also may dispute and disregard particular electoral votes, pursuant to statutory procedures requiring, inter alia, an initial challenge from a member of each house and the agreement of both houses to invalidate a particular vote. ${ }^{74}$ In either event, Congress is not to choose an executive from among its own ranks based on someone holding a

executive whose continued tenure in office would be wholly and directly dependent upon the sufferance of the legislature.").

${ }^{71}$ See U.S. CONST. amend. XII (providing that, in the event of no majority winner, the House was to choose the President from among the top three vote recipients and the Senate was to choose the Vice President from among the top two vote recipients), amending U.S. CONST. art. II, § 1, cl. 3; see also KURODA, supra note 67, at 104-05 (discussing House contingency election for President in 1800).

${ }^{72}$ See HARDAWAY, supra note 14, at 5 ("[T] he Electoral College has functioned far more successfully than was ever envisioned by the constitutional framers, and has, over the past 100 years, consistently produced clear-cut winners ...."); id. at 13 (arguing that the drafters assumed that it would be very unlikely that any presidential candidate after Washington would receive a majority of electoral votes); Wechsler, supra note 5, at 553 (arguing that, had the Electoral College functioned as expected, it would have been a nominating body, leaving selection mainly to the House); Ann Althouse, Electoral College Reform: Déjà Vu, $95 \mathrm{Nw}$. U. L. REV. 993, 995-96 (2001) (book review) ("It was thought at the time that the electors would typically find themselves unable to reach a majority, thus invoking the contingency that the House of Representatives would make the final choice. Some imagined that the electoral college would operate as little more than a nominating convention leading up to the House choice.").

${ }^{73}$ See Amar \& Amar, Succession, supra note 21, at 125 (arguing that in contingency election, Congress's discretion is cabined, limited to voting for candidates nominated by the Electoral College process).

${ }^{74}$ See 3 U.S.C. $§ 15$ (1994) (providing that every objection shall be signed by at least one Senator and one House member and that the two Houses concurrently may reject votes); see also id. $\S \S 15-18$ (establishing procedures for congressional objections to electoral votes). 
particular legislative seat and office (such as the speakership) or by virtue of that person having gained enough popularity within one house of Congress to secure that office. ${ }^{75}$

A member of Congress also is specifically prohibited from serving in the executive branch, a prohibition that some have argued is the key to separation of powers. ${ }^{76}$ A member of Congress may become President or serve in the cabinet, of course; however, she may do so only by resigning her congressional seat and by passing through whatever selection procedure is required for that executive office, be it election or Senate confirmation. This is particularly critical with regard to a member of Congress becoming President, as it ensures that she gains the support of the relevant national electoral constituency and not just of the state or local constituency that initially placed her in Congress. Separation of powers commands this intermediate selection step before a member of the legislature assumes the executive power.

\section{Separation of Powers and Succession}

Given the scope and nature of separation of powers, it is entirely inconsistent to have executive power devolve to a legislative officer, even on an acting basis, as occurs in the operation of $\S 19$. Most obviously, it establishes precisely what the framers expressly rejected during the Convention - Congress effectively selects a President from among its own ranks and someone assumes the executive power solely by virtue of her holding a seat and office in one house of Congress and of having gained enough support among members of the House to secure that office. ${ }^{77}$

Requiring the Speaker's resignation from the House, while perhaps rendering $\S 19$ constitutional under the Incompatibility Clause, does not resolve the separation of powers concerns. Having legislative officers in the line of succession creates negative incentives and conflicts of interest in carrying out congressional duties. For example, both the Speaker and the President Pro Tem, as members of Congress, play a role in the impeach-

${ }^{75}$ See Amar \& Amar, Succession, supra note 21, at 124 ("A person should not become President merely by currying favor with the legislature.").

${ }^{76}$ See U.S. CoNST. art. I, § 6, cl. 2 ("[N]o Person holding any Office under the United States, shall be a Member of either House during his Continuance in Office."); Calabresi \& Larsen, supra note 34, at 1048-49 (arguing that the Incompatibility Clause has strengthened separation of powers and has prevented the establishment of parliamentary government).

${ }^{7}$ See discussion supra notes 67-76 and accompanying text. 
ment, Senate trial, and possible removal of the President. ${ }^{78}$ This process may result in one or both legislative officers either becoming acting president or moving one step closer to the presidency, potentially warping their respective judgments when called upon to participate in the judicial process of impeachment. ${ }^{79}$

In 1868, during the impeachment of President Andrew Johnson, President Pro Tempore Ben Wade of Ohio was next in line to the presidency and was selecting the members of his cabinet at the same time that he was sitting as a juror and an active participant in Johnson's Senate trial. $^{80}$ Those "shenanigans" were a motivating force behind the 1886 amendment to the statute that established cabinet succession. ${ }^{81}$ Similar, albeit more remote, concerns were raised in 1998 during the impeachment of President Clinton. Speaker Newt Gingrich, in presiding over the House debates and vote on impeachment (and himself voting for impeachment), helped set in motion a process that could have moved him one step closer to the presidency. Considered alongside persistent and ongoing calls for an independent counsel to investigate (and perhaps bring about the impeachment and removal of) Vice President Al Gore, the entire process had a remote potential to place Gingrich in the White House.

The possibility of supplantation raises similar concerns of gamesmanship and manipulation. Imagine that the Secretary of State has become acting president. The Speaker, the President Pro Tem, and the rest of Congress could attempt to control and manipulate the acting president, on threat of immediate and unilateral removal and replacement by the Speaker,

${ }^{78}$ See U.S. CONST. art. I, § 2, cl. 5 ("The House of Representatives ... shall have the sole Power of Impeachment."); id. § 3, cl. 6 ("The Senate shall have the sole Power to try all Impeachments.").

${ }^{79}$ See Amar \& Amar, Succession, supra note 21, at 122; A. Amar, Mandates, supra note 29, at 385; Brown \& Cinquegrana, supra note 1, at 1420; Calabresi, Presidential Succession, supra note 50, at 156.

${ }^{80}$ See Amar \& Amar, Succession, supra note 21, at 123; A. Amar, Mandates, supra note 29, at 385; Brown \& Cinquegrana, supra note 1, at 1420. Johnson had succeeded to the presidency upon the death of President Abraham Lincoln, and the vice presidency remained vacant. See Amar \& Amar, Succession, supra note 21, at 123. Had Johnson been convicted and removed from office, it would have created a double vacancy and triggered the application of the succession statute. In 1868 , the original statute was in operation, meaning the President Pro Tem was to become acting president. Id.

${ }^{81}$ See Amar \& Amar, Succession, supra note 21, at 134; Brown \& Cinquegrana, supra note 1, at 1420; Calabresi, Presidential Succession, supra note 50, at 167; Truman, supra note 22, at 130. 
if the Secretary of State/acting president does not conform to the policy and political wishes and will of Congress. Such threat of removal would continue for the remainder of that presidential tenure, which, depending on the circumstances, might be almost an entire four-year term. The result would be an executive serving essentially at the pleasure of Congress, subject to immediate removal and replacement at any time, without the need to resort to ordinary impeachment procedures. ${ }^{82}$ The acting president would be forced to conform to Congress's policy preferences and to act more in the interests of pleasing Congress (actually one member of Congress) than in the public interest, under threat of immediate removal. ${ }^{83}$ Such an executive will lack the independence, initiative, and vitality that the Framers specifically sought to protect by limiting the legislative role in the selection of the executive and the executive branch and that must be protected in order for a system of separation of powers to function. ${ }^{84}$

Cabinet officers already are members of the executive branch, selected by the President to represent the same national electoral constituency and to help the President exercise the executive power. ${ }^{85}$ This gains particular force under the theory of the unitary executive. Under Article $I, \S 1$, the whole of the constitutional executive power is vested exclusively in the President. ${ }^{86}$ Cabinet officers have been hand-selected by the President to

${ }^{82}$ See Cinquegrana, supra note 3, at 127 (arguing that Framers did not want executive's tenure in office to be dependent upon the sufferance of the legislature). See also supra notes 34-38 and accompanying text.

${ }^{83}$ See Cinquegrana, supra note 3, at 119 (criticizing the "unbridled discretion" that $\$ 19$ places in the hands of the congressional leadership and its effect on the ability of the executive to act in the public, as opposed to congressional, interests); id. at 140 (arguing that the supplantation provisions "have no legitimate relationship to the legislative functions of Congress" and that no lawmaking purpose could be served by supplantation); see also id. at 117-19 (discussing an elaborate hypothetical in which the Speaker uses the underlying threat of supplantation to compel the acting president to appoint an independent counsel to investigate cabinet officers).

${ }^{84}$ See id. at 139 ("The looming omnipresence of a congressional power to supplant an Acting President would so clearly prevent the uninhibited performance of those functions as to require no further elaboration."); see also discussion supra notes 65-68 and accompanying text.

${ }^{85}$ See Calabresi, Presidential Succession, supra note 50, at 173 (arguing that senior cabinet officers represent the same constituency as President).

${ }^{86}$ See U.S. CoNST. art. II, $\S 1$, cl. 1 ("The executive Power shall be vested in a President of the United States of America."); see also Fitzgerald, supra note 13, at 756 ("Article II underscores its creation of a national constituency through its means of apportionment: there is only one President for the entire nation."); 
exercise a specific delegated portion of that executive power, with the President maintaining the ultimate power to select and to control the conduct of her subordinates. ${ }^{87}$ Separation of powers, grounded as it is in ensuring that the executive branch exclusively controls executive power, dictates that the full executive power devolve to someone who, prior to succession, exercised a delegated piece of that power under the control of the President.

The Secretary of State, for example, has been exercising delegated power over foreign policy, arguably the most important executive power and the one in which the President, by design or practice, plays the most central and exclusive role. ${ }^{88}$ This is the area in which the acting president would be required to act most quickly and decisively upon taking office, particularly in the face of a possible foreign crisis. The Secretary of State also has an ongoing (and presumably good) working relationship with the cabinet and the rest of the executive branch. This provides greater stability and continuity in the transition and greater legitimacy for the acting president, both within the executive branch and with the public. ${ }^{89}$

Lawson, supra note 66, at 1242 ("[T] hat power to execute the laws is vested, not in the executive department of the national government, but in 'a President of the United States of America.' ").

${ }^{87}$ See Calabresi, Political Parties, supra note 16, at 1501 (arguing that the President should be in charge of the entire executive branch); Calabresi \& Rhodes, supra note 9, at 1168 (arguing that the theory of the unitary executive commands that the President must retain the authority to give directives to the officers who assist him and to control that department); Lawson, supra note 66, at 1243 \& n.72 (arguing that President retains power to issue detailed and binding instructions to a cabinet secretary who has been given the power by Congress to promulgate regulations in some area).

${ }^{88}$ See United States v. Curtiss-WrightExp. Corp., 299 U.S. 304, 319-20 (1936) (emphasizing the unique role that the President plays in the area of foreign policy); Saikrishna B. Prakash \& Michael D. Ramsey, The Executive Power over Foreign Affairs, 111 YALE L.J.231,252-53 (2001) (arguing that the "President's executive power includes a general power over foreign affairs," given the understanding that foreign affairs power was included in the concept of executive power); see also Michael A. Carrier, All Aboard the Congressional Fast Track: From Trade to Beyond, 29 GEO. WASH. J. INT'L L. \& ECON. 687, 689 (1996) (arguing that the President's assumption of dominant foreign policy power has been more a matter of practice than constitutional design).

${ }^{89}$ See IRWIN UNGER \& DEBI UNGER, LBJ: A LIFE 292 (1999) (discussing Lyndon Johnson's decision to keep President Kennedy's advisers, congressional liaisons, and cabinet secretaries when he ascended to the presidency in the interest of continuity). 
As erroneous as Alexander Haig's declaration of control in March 1981 was, his ability to work inside the White House with other presidential aides helped to control and organize executive branch action during the early, uncertain crisis period after the President was shot. ${ }^{90}$ It is doubtful that the Speaker would have been able to work as quickly, or as well, within the White House and with White House staff.

Similarly, had the September 11 attack succeeded in killing or injuring both President George W. Bush and Vice President Dick Cheney, Secretary of State Colin Powell would have been better able than Speaker of the House Dennis Hastert to assume control of the executive branch, to oversee American military and diplomatic responses to the attack, to address and ease public concerns about national security, and to guide the nation through the crisis. This flows from Powell's starting position as a highranking member of the executive branch and a delegatee of executive power and from the fact that he would be a leading voice in the military and diplomatic actions in any event. Indeed, efforts immediately after the Tuesday morning attack appeared to focus on moving cabinet members to secure locations in order to ensure that the executive branch, through some cabinet officer, would remain at the head of the federal government if the attack succeeded against the President and Vice President. ${ }^{91}$

Unfortunately, Truman never mentioned separation of powers in proposing the new statute, and Congress considered separation of powers only from the standpoint of whether, under the Constitution, executive power could devolve to a legislative officer. ${ }^{92}$ No one addressed whether it is a normatively good idea to devolve executive power to a legislative officer, considering the nature and purpose of separation of powers as an independent value. Had Congress so considered the principle, it should have concluded that separation of powers supports succession by members of the cabinet.

${ }^{90}$ See Allen, supra note 1, at 64-66 (describing the early period after the assassination attempt on President Reagan, including concerns that it might have been the work of the Soviets or some other foreign enemy, and the response of Haig and other top advisers to the crisis).

${ }^{91}$ See Meet the Press (NBC television broadcast, Sept. 16, 2001) (interview with Vice President Richard Cheney, describing efforts to secure safety of himself and the rest of the cabinet to ensure that the head was not cut off of the federal government).

${ }^{2}$ See Amar \& Amar, Succession, supra note 21, at 134-35 (discussing congressional debates over constitutionality of legislative succession); Brown \& Cinquegrana, supra note 1, at 1424 (same). 


\section{B. Political Partisanship}

\section{Political Partisanship Considered}

a.

The Constitution of 1787 makes no mention of political parties; in fact, by relying on separation of powers as the primary structural principle, the Constitution arguably was "devised against part[ies]." viewed as factions, as "personal and irresponsible clique[s]"94 acting "contrary to the peace and safety of the people," deep and unbridgeable differences in national politics, their instability posing a danger to liberty. ${ }^{96}$

Madison provided the clearest explanation of this sentiment in The Federalist No. 10, in which he warned against a government in which the "public good is disregarded in the conflicts of rival parties, and that measures are too often decided, not according to the rules of justice and the rights of the minor party, but by the superior force of an interested and overbearing majority. would become incorporated into the operation of government. The solution, in Madison's view, was a republican government, in which the size and scope of the national government would take in a "greater variety of parties and interests," making it "less probable that a majority of the whole will have a common motive to invade the rights of other citizens."

${ }^{93}$ Hofstadter, supra note 16, at 70; see Calabresi, Political Parties, supra note 16, at 1484 ("The Framers of our Constitution were quite outspoken in voicing their dislike for 'factions' and 'parties." "); id. at $1494 \mathrm{n} .54$ ("[T] he vast bulk of our Constitution was designed to discourage parties and not to accommodate them.") (emphasis omitted); Michael Allen Gillespie, Political Parties and the American Founding, in AMERICANPOLITICALPARTIES ANDCONSTITUTIONALPOLITICS, supra note 16, at 17 (stating that the Constitution did not make provision for parties); James L. Sundquist, The Question is Clear, and Party Government is the Answer, 30 WM. \& MARY L. REV. 425, 425 (1989) (arguing that the Framers "originally conceived a nonpartisan government" and "designed the Constitution to deliberately obstruct and discourage the formation of national parties").

941 ARTHUR M. SCHLESINGER, HISTORY OF U.S. POLITICAL PARTIES, at XXXiv (1973).

${ }_{95}$ Id. (quoting THOMAS HoBBES, LEVIATHAN 125 (Dutton 1965) (1651)).

${ }^{96} \mathrm{Id}$.

${ }^{97}$ The FederalistNo. 10, at 45 (James Madison) (Clinton Rossiter ed., 1961).

${ }^{98}$ See id. at 51; see also HOFSTADTER, supra note 16, at 24-25 (discussing the Madisonian view of parties as an unavoidable product of a free state); Calabresi, Political Parties, supra note 16, at 1488 (describing support for Madisonian view 
But even if discouraged, parties are not constitutionally prohibited. ${ }^{99}$ Indeed, one commentator has suggested that Madison did not condemn all parties: he condemned those opposed to the rights of other citizens or to the interests of the community but not those acting consistent with the permanent interests of the community. ${ }^{100}$ In other words, where the partisan conflict was between competing political groups striving to defend the government each believed the Constitution had established, parties were not inconsistent with or contrary to the facially anti-party Constitution. ${ }^{101}$ Of course, this creates intractable definitional problems, because whether a particular party is defending the Constitution or opposing the community interests and the rights of other citizens depends entirely upon one's perspective. ${ }^{102}$

$b$.

Organized political parties developed almost immediately during George Washington's first term, notably around divisions over Alexander

that parties were a source of trouble that could be controlled through a wisely constructed government and constitutional structure); see generally Larry D. Kramer, Madison's Audience, 112 HARV.L. REv. 611 (1999)(discussing Madison's theory on parties and factions and the impact of that theory).

${ }^{99}$ See Mark V. Tushnet, The Constitution and the Nationalization of American Politics, in A WORKABLE GOVERNMENT? THE CONSTITUTION AFTER 200 YEARS 166 (Burke Marshall ed., 1987) (arguing that the Supreme Court "has not found any tension between the Constitution and the national party system"); see also Charles R. Kesler, Political Parties, the Constitution, and the Future of American Politics, in AMERICAN POLITICAL PARTIES AND CONSTITUTIONAL POLITICS, supra note 16, at 229 ("The United States Constitution is a partisan document ....").

${ }^{100}$ See Gillespie, supra note 93, at 19-20 (arguing that Madison's "condemnation of faction is not a blanket condemnation of all parties," but only those "opposed to the rights of other citizens or to the permanent and aggregate interest of the community") (emphasis omitted); see also Lloyd N. Cutler, Now is the Time for All Good Men . . , 30 WM. \& MARY L. REv. 387, 389 (1989) [hereinafter Cutler, Now is the Time] (arguing that Madison's definition "would not appear to cover a broadly based national political party that cuts across narrow interest groups").

${ }^{101}$ See Gillespie, supra note 93, at 43 (suggesting that, under Madison's view, early parties were not factions because "they did not seek to undermine the rights of their fellow citizens and did not aim at a goal that was adverse to the permanent and aggregate interests of the community").

${ }^{102}$ See id. at 36 ("[E]ach group understood its own party organization to be compatible with and indeed essential to the preservation of republican government, while at the same time viewing the opposition party as a threat to the continued existence of republicanism."). 
Hamilton's plans to assume state Revolutionary War debts and to create a national bank, as well as around disagreements over the United States' position with regard to the French Revolution. ${ }^{103}$ Hamilton, as Washington's Treasury Secretary, sought to build support for these policies by forging connections among like-minded members of Congress and between Congress and the Treasury Department; Representative James Madison and Secretary of State Jefferson countered with similar efforts to defeat these plans. ${ }^{104}$ Thus were the early parties born alongside these controversies, even while George Washington, in his Farewell Address, warned against the "baneful effects of the spirit of party generally."10s

Many have argued that the development of parties, unexpected though it might have been, was necessary for the survival and success of the American Constitution. ${ }^{106}$ This is particularly true in the context of selection; the chief functions of the early political parties involved organizing and coordinating electoral campaigns, establishing party platforms and tickets, formulating positions, and arranging the government to ensure implementation of a chosen agenda. ${ }^{107}$ Most notably, political

${ }^{103}$ See HOFSTADTER, supra note 16 , at 87 ; id. at 89 (quoting Jefferson's letter of June 1793 to James Monroe, stating that the war in Europe "kindled and brought forward the two parties with an ardour which our own interests merely, could never excite"); Kramer, supra note 16, at 273 ("Parties grew alongside the escalating series of political controversies ....").

${ }^{104}$ See Kramer, supra note 16, at 274; see also Gillespie, supra note 93, at 39 (arguing that Jefferson organized the Republican party to counter "the threat to republicanism that he perceived in Hamilton's plans").

${ }^{105}$ George Washington, Farewell Address, in 1 A COMPILATION OF THE MESSAGES AND PAPERS OF THE PRESIDENTS 218 (James D. Richardson ed., 1901). But see HOFSTADTER, supra note 16, at 91 (arguing that Washington's bipartisan prestige was lost in his second administration and that he became a partisan of Hamiltonian Federalism).

${ }^{106}$ See HOFSTADTER, supra note 16, at 70 ("[I]t seems doubtful whether this Constitution ... could have been made to work if such a functional agency as the party had not sprung into the gap to remedy its chief remaining deficiencies."); Mansfield, supra note 16, at 2 (arguing that parties "appear to be necessary parts of the constitution in the informal sense"); Sundquist, supra note 93, at 426 (arguing that the Framers "found it absolutely necessary to concert the organs of power that they had dispersed").

${ }^{107}$ See Kramer, supra note 16, at 274 (arguing that, particularly after the election of 1796, "fledgling party managers looked for ways to organize and coordinate campaigns"); id. at 273 (arguing that parties offered supporters a national organization capable of formulating positions and managing campaigns); Daniel Hays Lowenstein, Associational Rights of Major Political Parties: A 
parties made it possible for one candidate regularly to gain a majority in the Electoral College and for the College successfully to select (rather than simply nominate) a President by reducing the number of presidential candidates and by creating broad supporting constituencies for those candidates. ${ }^{108}$

It is significant that the first structural change to the Constitution, the first formal change in the procedures for selecting federal officials, reflected the political partisanship principle. Under the original design of the Electoral College, each elector cast two votes for President, with the top vote-getter becoming President and the second vote-getter becoming Vice President; it was envisioned that the two best candidates for President would prevail and together form the executive branch. ${ }^{109}$ In 1789 and 1792 , this worked well largely because George Washington was a candidate in both elections and the Framers had expected him to be the only real choice for the presidency. ${ }^{110}$ Most electors viewed Washington as the only candidate for President and saw themselves as casting one vote for Washington as President and a second vote for another candidate as Vice President. ${ }^{111}$

By 1796, the first election without Washington, this system no longer was effective, as there was no single clear choice for President. The formal party structures and their practices began to play a role in the election, with each party designating a preferred choice for each executive office and instructing electors to vote accordingly. ${ }^{112}$ This worked so well that in

Skeptical Inquiry, 71 TEX. L. REV. 1741, 1761 (1993) ("[P]olitical parties provide a means by which the nearly infinite conceivable policy viewpoints are funneled into a manageable number.").

${ }^{108}$ See Casper, supra note 11, at 178 (arguing that the formation of political parties helped redirect the Electoral College); Wechsler, supra note 5, at 553 (arguing that the rise of parties has enabled the Electoral College successfully to select a President).

${ }^{109}$ See KURODA, supra note 67, at 172; see also U.S. CONST. art. II, § 1, cl. 3 (providing that the top vote-getter with a majority in the Electoral College would be President and that the next vote-getter would be Vice President) (amended by U.S. CONST. amend. XII).

${ }^{110}$ See KURODA, supra note 67, at 57, 129.

${ }^{11}$ See id. at 129; see also HARDAWAY, supra note 14, at 91 (arguing that, with Washington running in 1788 and 1792, the only office in contention was Vice President).

112 See HARDAWAY, supra note 14, at 91 ("By 1796, however, it became apparent that a party putting forth a candidate had a definite idea of which candidate it wanted for president and which candidate it wanted for vice president."); KURODA, supra note 67, at 129 (arguing that, by 1796, many Americans thought 
neither of the next two elections was a party able to elect both a President and Vice President of its choice through the ordinary Electoral College process.

The election of 1796 produced a divided executive, as Federalist presidential choice John Adams won the presidency, with Republican presidential choice Thomas Jefferson finishing second in the voting and becoming Vice President. ${ }^{113}$ The Federalists, wanting to avoid a tie and to ensure that Adams won the necessary electoral majority, ordered several Federalist-committed electors to slough or withhold votes from Federalist vice presidential choice Thomas Pinckney. ${ }^{114}$ However, the electors sloughed too many votes, allowing Jefferson to finish second and to claim the vice presidency. ${ }^{115}$

In 1800 , this process resulted in the election being thrown into the House. Republican presidential choice Jefferson and vice presidential choice Aaron Burr finished in a tie in the Electoral College, when party officials ordered electors to vote straight for the two Republican candidates, rather than sloughing votes and renewing the risk of a split executive. ${ }^{116}$ In the House, Federalists threatened to invert the candidates, making Burr President instead of Jefferson, despite the fact that Jefferson obviously was the preferred, and more qualified, choice for President and that such a vote would have gone against the expressed will of the public and of the

of separate votes for President and Vice President as the natural practice).

${ }^{113}$ It perhaps is a mark of how much the system has evolved that in 1796, Jefferson finished second in the presidential race and became President of the Senate. Two hundred years later, in 1996, Robert Dole finished second in the presidential race and became a spokesman for Viagra, Visa, and Pepsi, doing commercials with singer Britney Spears.

${ }^{114}$ See HARDAWAY, supra note 14, at 91; KURODA, supra note 67, at 65-71; Akhil Reed Amar \& Vik Amar, President Quayle?, 78 VA. L. REV. 913, 921 (1992) [hereinafter Amar \& Amar, President Quayle?].

${ }^{115}$ See HARDAWAY, supra note 14, at 91 (stating that "Federalists withheld too many votes, and Jefferson slipped in as the vice president'); KURODA, supra note 67, at 70-71 (discussing Electoral College voting in 1796 election); Amar \& Amar, President Quayle?, supra note 114, at 921 (same); Beverly J. Ross \& William Josephson, The Electoral College and the Popular Vote, 12 J.L. \& PoL. 665, 676 (1996) (same); see also Amar \& Amar, President Quayle?, supra note 114, at 922 (arguing that no move for amendment followed the 1796 election because many did not see a divided executive as a concern).

${ }^{116}$ See HARDAWAY, supra note 14, at 91; KURODA, supra note 67, at 99; Amar \& Amar, President Quayle?, supra note 114, at 922; Josephson \& Ross, supra note 67, at 155 (arguing that Republicans were afraid of losing the vice presidency if they sloughed votes). 
Republican party. ${ }^{117}$ The contingency election finally required thirty-six ballots, the influence of Hamilton, and enough Federalists abstaining (not one Federalist voted for Jefferson in the House election) to permit state delegations to make Jefferson President. ${ }^{118}$

The Twelfth Amendment followed. Ratified in 1804, it established separate Electoral College ballots, with designated candidates for each office and electors casting one vote for each office. ${ }^{119}$ The risk of inversion, as in 1800, was eliminated; a vice presidential candidate would not become President, nor would the runner-up presidential candidate become Vice President. In fact, the Amars argue that eliminating the risk of inversion-not eliminating the risk of a split executive-was the primary motivation for the amendment. ${ }^{120}$

For our purposes, the amendment recognized and accommodated the existence of formal political parties, conforming formal constitutional selection procedures to informal partisan practices and making these practices the systemic norm. ${ }^{121}$ Party choices were to prevail, by ensuring that the party winning a majority of votes in the Electoral College would capture and control both executive offices. ${ }^{122}$

c.

American parties are not ideologically pure or consistent. ${ }^{123}$ They "are not especially programmatic, which is to say they are more concerned with

${ }^{117}$ See HARDAWAY, supra note 14, at 91; KURODA, supra note 67 , at 100-01 (discussing Republican concerns that Federalists would invert the candidates and make Burr President); Amar \& Amar, President Quayle?, supra note 114, at 922.

${ }^{118}$ See HARDAWAY, supra note 14, at 92; KURODA, supra note 67, at 104-05; $i d$. at 105 (noting that Jefferson became President in the House election without the vote of a single Federalist and that Republicans would not forgive "spiteful" Federalists).

${ }^{119}$ See U.S. CONST. amend. XII; see also HARDAWAY, supra note 14, at 92.

${ }^{120}$ See Amar \& Amar, President Quayle?, supra note 114, at 922-23 (emphasizing that it was the inversion problem, not the split executive, that was the motivating force behind the Twelfth Amendment).

${ }^{121}$ See KURODA, supra note 67, at 172 ("A national political party with an organization capable of nominating presidential candidates and offering a program and philosophy that attracted support across the country made archaic the Constitution's provision for each elector to cast two votes for President."); Amar \& Amar, President Quayle?, supra note 114, at 923 ("In the end, then, the Twelfth Amendment makes the Constitution safe for strong parties...."); Mansfield, supra note 16, at 12 (arguing that the Twelfth Amendment gave unacknowledged but real constitutional recognition to political parties).

${ }^{122}$ See KURODA, supra note 67, at 172.

${ }^{123}$ See Lowenstein, supra note 107 , at 1761 ("American parties are generally regarded as among the least ideologically defined in the world ...."). 
getting people elected than with getting them elected for any specific purpose."124 American parties fall somewhere in the middle of Tocqueville's continuum of parties, which distinguishes great parties, devoted to principles over consequences, from small parties, entirely or largely without political faith. ${ }^{125}$ Parties do serve as rough proxies for ideology, or at least for a commitment to some common set of public policies and positions and loose combination of ideological and policy views. ${ }^{126}$ Membership in a particular party labels an official as adhering to those policies across the political branches of government. ${ }^{127}$ However, what a party stands for is broad and flexible enough to leave substantial room for disagreement; when ideology and electoral success collide, the former generally yields to the interests of winning. ${ }^{128}$

This helps explain the prevalence of and preference for ticket-splitting and divided federal government, with voters supporting Senators or Representatives of one party and a President of another and changing party support from election to election. ${ }^{129}$ The major parties are so ideologically broad that a single voter, voting as a member of three distinct electoral constituencies, may support candidates from different parties in each of those constituencies. Split tickets and divided government have, since World War II, become the preferred choice of the voters. ${ }^{130}$

${ }^{124}$ Kramer, supra note 16 , at $278-79$.

${ }^{125}$ See 1 AleXIS DE TOCQUEVILLE, DEMOCRACY IN AMERICA 175 (George Lawrence trans., J.P. Mayer ed., 1969).

126 See Lowenstein, supra note 107, at 1761 ("[T]he Democrats and Republicans have always been associated with at least a loose clustering of ideological and policy views."); see also Calabresi, Political Parties, supra note 16 , at 1530 (arguing that parties serve as good predictors of legislative voting behavior).

${ }^{127}$ See Calabresi, Political Parties, supra note 16, at 1530 (discussing labeling function of party membership); Lowenstein, supra note 107, at 1762 (arguing that candidates have an incentive to associate themselves with the party label and to make that label attractive to voters).

${ }^{128}$ See Kramer, supra note 16, at 279.

${ }^{129}$ See Calabresi \& Larsen, supra note 34, at 1092 ("[O]ur Constitution allows for divided party control of the Presidency and of Congress ...."); Wilson, supra note 55, at 23 (describing the increase in split-ticket voting).

${ }^{130}$ See Amar \& Amar, President Quayle?, supra note 114, at 915 (discussing the "dramatic increase in ticket splitting generally by American voters over the last fifty years" and the fact that, in 1984, voters in half of the congressional districts supported House and presidential candidates of different parties); Calabresi, Political Parties, supra note 16, at 1510 (describing the option of voting a split ticket as the preference since the New Deal); Calabresi \& Larsen, supra note 34, at 1092 \& n.239 (stating that from 1946 to 1992, different parties have controlled 
Party membership links candidates for different offices in the public mind, to a candidate's advantage or disadvantage, and provides voters with information about particular candidates for particular offices. A congressional candidate's association with a popular (or unpopular) President through the medium of party membership often will influence and affect the outcome of the election in that House district. ${ }^{131}$ Voters often express displeasure with the President by voting against members of her party in House and Senate elections; the presidential party generally loses congressional seats, and some policy influence, in midterm elections. ${ }^{132}$

However, the House, Senate, and executive remain distinct departments chosen by distinct electoral constituencies: three different voices of the People speaking through three different channels. ${ }^{133}$ The vote against congressional candidates of the presidential party, while perhaps motivated by the unpopularity of the President and the partisan connection between the President and those congressional candidates, cannot necessarily be read as a vote against the President or as an indication of the voters' actual intention to remove the President or her party from the White House. It was not the President's national constituency (or coalition of state constituencies) that voted in the midterm election, but the smaller state and local constituencies. Voters in these smaller constituencies may have been motivated not by opposition to the sitting President as much as by a desire

Congress and the White House two-thirds of the time); Epstein, supra note 55, at 568 ("The fact that you observe (at least since 1950) a consistent set of outcomes-here with divided government-suggests that this is what people in general want."); Malbin, supra note 16, at 77-79 (discussing the increase in ticketsplitting and divided government, with graphics showing the rise of ticket-splitting from 1900 through 1988).

${ }^{131}$ See Calabresi, Political Parties, supra note 16, at 1528-29 (discussing the advantages to a candidate of a link to a faithful party agent and the disadvantage of a link with a faithless party agent).

${ }^{132}$ See Ceaser, supra note 55, at 186 ("[A]though the president holds his term for four years, a new sounding is taken every two years, and a president can lose influence in policy matters if his party suffers a severe setback in the midterm election."); Cutler, Now is the Time, supra note 100, at 401 ("[I]t is a political truism that the President's party usually loses House and Senate seats in an off-year election....").

${ }^{133}$ See Calabresi \& Larsen, supra note 34, at 1093 (describing the "complex and highly sophisticated" three-tiered method for "sampling the national will" of the people); see also discussion supra notes 57-61 and accompanying text. 
to have Congress, through control by a different party, provide some partisan balance to the President. ${ }^{134}$

The President may lose influence or the ability to push an agenda after two years, but she does not lose the White House and neither does her party. In 1996, two years after his Democratic Party lost control of both the House and Senate, President Clinton was reelected with a forty-seven percent national popular plurality in an election featuring three major candidates and an Electoral College landslide.

\section{d.}

The development of political parties within the Constitution's separation of powers structure has created a hybrid system, with partisanship not overcoming separation of powers, but separation of powers not eliminating parties from the system. ${ }^{135}$ The party structures work within the system of separation of powers, joining informally what the Constitution separates formally. ${ }^{136}$ The President necessarily has policy allies in Congress in the members of her own party. ${ }^{137} \mathrm{~A}$ party able to control all of

${ }^{134}$ See Calabresi, Political Parties, supra note 16, at 1510 (arguing that a divided government allows voters to have, for example, a President committed to shrinking the federal government and Congressmen committed to bringing home pork projects).

${ }^{135}$ See id. at 1532 (arguing that political parties play a valuable role in the separation of powers system); Wilson, supra note 55, at 19 ("The parties have not overcome the separation of powers, at least to the degree critics of the separation would like.").

${ }^{136}$ See HOFSTADTER, supra note 16, at 70-71 (arguing that parties became a necessary part of the system of government and turned the Constitution into a working instrument of government); Kesler, supra note 99, at 229 (arguing that political parties bring coordination and organization to institutions that formally were separated); Malbin, supra note 16, at 75 ("The parties ... help[ ] to bring some coordination to institutions that formally were separated."); Mansfield, supra note 16 , at 8 (arguing that political parties are "voluntary associations outside of the Constitution that help to make it work as it does"); Wilson, supra note 55, at 18 (arguing for a "party system that can overcome the separation of powers by bringing together under informal arrangements what the founders were at pains to divide by formal ones").

${ }^{137}$ See Kesler, supra note 99, at 243 ("[P]arties multiplied presidential ties to Congress, and probably strengthened presidential influence over policy-making."); see also Cutler, Now is the Time, supra note 100, at 389 (arguing that the elected President and elected congressmen of the same party have greater natural affinity for cooperation with one another and this affinity offsets the "institutional 
the political branches of the federal government arguably will be better able to enact the core policy agenda that won electoral approval, with the President and a congressional majority committed to the same policies and working together to achieve those policies. ${ }^{138}$ Historically, a President is more likely to get her policy agenda passed and more likely to be able to take fast, effective action when she has a congressional majority. ${ }^{139}$ Of course, because those policies are so broad and diverse in these largely nonideological parties, it is possible that elected officials from the controlling party still will not agree entirely as to what those policy priorities are. ${ }^{140}$

Nothing guarantees that the President will have that legislative majority, given the preference for ticket-splitting and divided government. ${ }^{141}$ Commentators have argued for broad constitutional changes

wariness" between the executive and legislative branches in the exercise of their shared powers); Malbin, supra note 16, at 75 ("The parties work across the branches of government ...."); Sundquist, supra note 93, at 426 (arguing that political parties were the necessary organ to bring together the House, Senate, and executive branch).

${ }^{138}$ See Cutler, Now is the Time, supra note 100, at 398-99 (arguing that all the acknowledged great Presidents have presided over unified governments in which they have been able to pass their legislative agendas); Cutler, To Form a Government, supra note 55, at 6 (arguing for the government to have the ability to formulate and carry out an effective overall program, which is achieved when the same party has a majority in both the executive and legislative branches); see also Erwin Chemerinsky, The Question's Not Clear, But Party Government is Not the Answer, 30 WM. \& MARY L. REV. 411, 414-15 (1989) (arguing that a party able to control both the presidency and Congress will be able to enact its policies, which might not be a good thing, depending on one's views of the party in control at a given moment).

${ }^{139}$ See Cutler, Now is the Time, supra note 100, at 398-99 (arguing that the most successful Presidents had congressional majorities, with Ronald Reagan and his 1981 tax cut being the lone exception); $i d$. at 396-97 (discussing the example of Woodrow Wilson and his loss of policy success after his party lost control of the Senate in 1918); Cutler, To Form a Government, supra note 55, at 11 (arguing that a system that makes divided government possible has succeeded only when some unusual event has brought the country together and created substantial consensus, such as war or the Great Depression); Sundquist, supra note 93, at 428 ("[T] Presidents in history whom we revere were the strong Presidents who were able to get their programs accomplished through the instrument of party government.").

${ }^{140}$ See Calabresi \& Larsen, supra note 34, at 1103 (questioning the assumption that unified party control will bring about more major legislative activity).

${ }^{141}$ See Sundquist, supra note 93, at 427 ("Ticket splitting gave us divided government . . . ."); see also discussion supra notes 129-34 and accompanying text. 
to establish pure party government in place of separation of powers, guaranteeing that one party would control both political branches at a given time and, presumably, would be better able to enact its policy agenda. ${ }^{142}$ They argue that such a system would remedy the perceived weaknesses of a separation of powers system by establishing governmental accountability and by enabling the government to act more quickly and more forcefully. ${ }^{143}$ By contrast, others prefer divided government and its effect of preventing a President from acting too singularly, dramatically, and forcefully. ${ }^{144}$

The Framers originally were concerned with conflicts and rivalries between the branches, particularly with the system's tendency towards aggrandizement of the legislature over the executive. ${ }^{145}$ In the early period of the nation, party rivalries centered around those questions of the structure and power of government, with the Federalists and Republicans fighting over arguably differing visions of the Constitution and the federal government. ${ }^{146}$

${ }^{142}$ See Cutler, To Form a Government, supra note 55, at 13 (proposing numerous constitutional changes, including elimination of the Incompatibility Clause).

${ }^{143}$ See Cutler, Now is the Time, supra note 100, at 398 ("A unified government usually will be held accountable for its errors and omissions . . . at the next election."); Cutler, To Form a Government, supra note 55, at 11-12 (arguing that a President in a divided government cannot achieve his program, but the public cannot fairly hold him accountable for that failure, because he does not have the power to execute and legislate that program); Sundquist, supra note 93, at 426 (arguing that bringing about pure party government would bring back the original political system).

${ }^{144}$ See Chemerinsky, supra note 138, at 414-15 ("In a country with deep ideological divisions and no consensus ... the best government may be one of 'muddling'-a government that acts by compromises, often incrementally rather than dramatically."); Epstein, supra note 55, at 567 (arguing that there should be a "strong presumption that the more legislation you have, the worse that government works").

${ }^{145}$ See THE FEDERALIST No. 48, at 277 (James Madison) (Clinton Rossiter ed., 1961) ("The legislative department is everywhere extending the sphere of its activity and drawing all power into its impetuous vortex.").

${ }^{146}$ Compare Letter from Thomas Jefferson to John Melish (Jan. 13, 1813), in ThOMAS JEFFERSON, WritingS 1268, 1268-69 (Merrill D. Peterson ed., 1984) (suggesting that Hamilton and the Federalists favored an English monarchy and wanted to establish such a system in the United States, using the Constitution only as a stepping stone, while the "party called republican" was "steadily for the support of the present constitution"), and id., Letter from Thomas Jefferson to George Washington (May 23, 1792), 985, 988 (describing Republicans "who espoused the same government for it's intrinsic merits"), with ALEXANDER HAMILTON, An Address to the Electors of the State of New York (Mar. 21, 1801), in SELECTED WRITINGS AND SPEECHES OF ALEXANDER HAMILTON 465, 470 
This was a period that Tocqueville described as guided by "great political parties."147

Established parties and a stabilized federal system mean that the parties, or at least the major parties, share a commitment to certain basic constitutional principles and no longer contest the basic form or powers of the government. ${ }^{148}$ Although policy disputes often are phrased in terms of "big" as opposed to "small" government, or of returning power to the states, parties generally argue not about broad structural constitutional principles, but about the material political interests of the moment. ${ }^{149}$ Rival parties, as opposed to rival branches, now conflict with and check one another, particularly when a different party controls each branch. ${ }^{150}$

Conflicts between the branches-as between President Clinton and the Republican-controlled Congress in the late 1990s or between President Reagan and the Democrat-controlled Congress in the 1980s-properly are viewed as partisan conflicts rather than as branch conflicts affecting the basic form and power structure of government. Structural arguments as to the power balance between the executive and legislative branches and as to which branch should exercise which powers depend more on which party controls a given branch at a given moment. As one commentator put it:

we have gazed at the spectacle, all the more ridiculous because the partisans are so serious, of Republicans defending the powers of Congress under the presidency of Franklin Roosevelt and the prerogatives of the

(Morton J. Frisch ed., 1985) (stating that the Antifederalists "have openly avowed their attachment to the excessive principles of the French revolution"), and id. at 478 (describing the split as a "contest between the tyranny of jacobinism, which confounds and levels every thing, and the mild reign of rational liberty").

${ }^{147}$ See 1 DE TOCQUEVILLE, supra note 125, at 176-77 (arguing that there were no signs of great political parties following the demise of the Federalists and the rivalry with the Republicans).

${ }^{148}$ See Kesler, supra note 99, at 231 (arguing that "political parties have little to say about the Constitution's relevance to their own functions").

${ }^{149}$ See id. ("It has been a long time, for example, since the G.O.P. objected to a proposed new federal program not simply because it was spendthrift or imprudent, but because it was unconstitutional.").

${ }^{150}$ See HOFSTADTER, supra note 16, at 81 (discussing Madison's argument, during the second Washington Administration, for using parties to check one another); see also Epstein, supra note 55, at 571 ("[V]oters have a greater preference for divided government as a way to slow down the political juggernaut."). 
executive under Ronald Reagan, and of Democrats performing the same acrobatic maneuver in reverse. ${ }^{151}$

This is best illustrated in the frequent conflicts over Senate confirmation of executive appointments and in the arguments about the responsibility of each branch in the appointment process. A Convention compromise gave the Senate a role in executive appointments, creating a powerful but silent check on favoritism in the exercise of the appointment power, but leaving the ultimate choice with the President. ${ }^{152}$ Members of one party in the Senate act differently (and expect the President to act differently) depending on whether or not they are in party agreement with the President and (presumably) with a particular nominee. Partisanship affects the manner in which, and how rigorously, one party in the Senate exercises that check and how much control the President ultimately has over her appointments. $^{153}$

George Washington pointed to this very inconsistency in the execution of constitutional functions, and the subsequent desire for political revenge, as a problem with political partisanship. ${ }^{154}$ Washington's concerns encompassed the larger notion that the majority party ought to be hesitant to run roughshod over the minority party, knowing that they "might very soon find themselves in the minority and in danger of finding their ox being gored." "155

${ }^{151}$ Mansfield, supra note 16, at 9.

${ }^{152}$ Compare THE FEDERALIST No. 76, at 425 (Alexander Hamilton) (Clinton Rossiter ed., 1961) (stating that Senate confirmation has a "powerful, though, in general, a silent operation" serving as "an excellent check upon a spirit of favoritism in the President"), with id. No. 65, at 364 (Alexander Hamilton) (stating that the executive is to be the principal agent in the appointment process); see also discussion supra notes 64-66 and accompanying text.

${ }^{153}$ Cf. Paul R. Verkuil, The Purposes and Limits of Independent Agencies, 1988 DukE L.J.257, $260 \mathrm{n} .9$ (arguing that the defeat of Judge Robert Bork's nomination to the Supreme Court either was a triumph of politics over reason or reason over politics, depending on one's political outlook).

${ }^{154}$ See Washington, Farewell Address, supra note 105, at 219 ("The alternate domination of one faction over another, sharpened by the spirit of revenge natural to party dissension, ... is itself a frightful despotism.").

${ }^{155}$ See Calabresi, Political Parties, supra note 16, at 1515. Such hesitancy has not been the rule, however. See CARTER, supra note 64, at 129-31 (arguing that the arguments, criticisms, and opposition that Thurgood Marshall faced from Republicans to his nomination to the United States Supreme Court in 1967 were similar to those that Robert Bork faced from Democrats in 1987). 


\section{Political Partisanship and Succession}

Partisanship and double-vacancy succession have a long and illustrious history together. The original 1792 statute established legislative succession partly out of partisan motivations: the Federalist-controlled Congress wanted to keep Republican Secretary of State Thomas Jefferson out of the line of succession. ${ }^{156}$

Given the close link between partisanship and separation of powers, ${ }^{157}$ it follows that the partisanship problems with $\S 19$ are similar to the separation of powers problems. Only the motivation for congressional action changes - from a grab for power in the name of aggrandizement of the legislative branch at the expense of the executive, to a grab for power in the name of partisan politics and the aggrandizement of one political party at the expense of another. The problem with the current succession order is not that the Speaker is next in line but that the Speaker may be, and often is, of a different party than the President.

A recent example illustrates. When Democratic President Clinton nominated attorney Bill Lan Lee as Assistant Attorney General in charge of Civil Rights, Senate Republicans decried Lee's former role as a liberal "activist" attorney and did not permit the nomination to be brought to a floor vote. They warned that Lee's prior litigation positions suggested that he would try to expand the enforcement of federal civil rights laws beyond their intended scope and that he would enforce not the laws that Congress had written but the laws that he wanted or that fit his personal preferences. However, when Republican President George W. Bush nominated former Senator John Ashcroft, a conservative Republican, as Attorney General, Senate Republicans spoke only of Ashcroft's commitment and duty as Attorney General to enforce the laws as written, even those with which he emphatically did not agree, against which he had voted and argued as a legislator, and which he believed went too far. Yet no one explained why Lee would not have been just as committed or felt just as duty-bound to enforce all laws as written.

Meanwhile, in opposing Ashcroft's nomination, Senate Democrats, no longer in party agreement with the President, emphasized that the "advice and consent" provision of the Constitution does not mean "advice and rubber stamp what the President wants" but instead commands and requires them to take a close, hard look at all nominees and nominations and to oppose vigorously those nominees with whom they may disagree, such as Ashcroft. In other words, the change in presidential administrations, and the consequent change in the role of each party's Senate caucus, reversed the arguments each made in carrying out the confirmation function. See id. at 15 (stating that there is no consensus as to what "close scrutiny" in the confirmation process involves).

${ }^{156}$ See Amar \& Amar, Succession, supra note 21, at 132; Brown \& Cinquegrana, supra note 1, at 1418.

${ }^{157}$ See discussion supra notes $135-55$ and accompanying text. 
The statute still creates conflicts of interests and negative incentives for Congress. The supplantation provisions pose the same danger of gamesmanship and manipulation of the acting president by a Speaker and the same threats to the acting president's independence and vitality. ${ }^{158}$ In fact, because the rivalry between the two major political parties has become more prominent than the rivalry between the two political branches, such shenanigans will arise only where Congress and the White House are controlled by different parties. It seems unlikely that a Republican Congress would attempt to impeach a Republican President (at least in the absence of true, serious public wrongdoing) or that a Democratic Speaker would supplant, or threaten to supplant, a Democrat acting as President.

In addition, Congress's Twenty-Fifth Amendment responsibility to confirm a nominee to fill a vice presidential vacancy ${ }^{159}$ becomes entwined with these partisan conflicts when succession passes through the Speaker. A congressional majority of one party might delay confirmation of a vice presidential nominee from the rival party because the Speaker remains next in line for the presidency so long as the vice presidency remains vacant. Commentators have suggested that the lengthy, five-month delay by the Democrat-controlled Congress in confirming Republican Nelson Rockefeller as President Ford's Vice President in 1974, after Ford had ascended to the presidency, was linked to the House majority's desire to keep then-Speaker Carl Albert, a Democrat, next in the line of succession. ${ }^{160}$

The flipside is that the ordinary cabinet confirmation process during divided government might become even more difficult or more contested if the Senate is aware that it is confirming the person who also is to be third in line to the presidency. ${ }^{161}$ It might change the qualifications sought in

${ }^{158}$ See Cinquegrana, supra note 3, at 117-19 (presenting hypothetical of a Democratic Speaker trying to force a Republican Secretary of State/acting president to call for an independent counsel investigation or to sign a particular piece of legislation or take some other executive action through threat of supplantation); see also discussion supra notes 82-84 and accompanying text.

${ }^{159}$ See U.S. CoNST. amend. XXV, $§ 2$ ("Whenever there is a vacancy in the office of the Vice President, the President shall nominate a Vice President who shall take office upon confirmation by a majority vote of both Houses of Congress.").

${ }^{160}$ See Amar \& Amar, Succession, supra note 21, at 128; Calabresi, Presidential Succession, supra note 50, at 167.

${ }^{161}$ Cf. Amar \& Amar, Succession, supra note 21, at 131 (suggesting the creation of a cabinet position of "First Secretary," who is to be the second presidential successor and whose confirmation would take into account her specific role as 
cabinet nominees, with Presidents seeking to appoint cabinet officials with higher national profiles who might have greater popular recognition and support in the event one becomes acting president. Presidents also might avoid appointing cabinet officers who are not constitutionally eligible to assume the presidency. ${ }^{162}$

In arguing for legislative-specifically Speaker-succession, President Truman explicitly recognized and sought to accommodate the partisanship principle. Truman understood that, while not ideologically pure, political parties reflect a commitment to some set of policies and a connection among candidates and voters sympathetic to those policies. ${ }^{163} \mathrm{He}$ believed, correctly, that it was important that the same political party maintain control of the White House in the event of a double vacancy and that any succession scheme should ensure retention of party control. ${ }^{164}$ If the voters of the national electoral constituency place one party in the presidency, that party should retain the presidency for the full four-year term; there should not be a party change if and when $\S 19$ is triggered.

Where Truman went wrong was in his belief that Speaker succession was the way to ensure the continuation of party control. He argued that the majority in the House of Representatives ordinarily was in party agreement with the President, meaning the Speaker would be as well. As a result, Speaker succession would enable the same party to maintain control of the White House. He specifically contrasted this with succession by the President Pro Tem, arguing that the Senate was more likely to have a majority hostile to the President and was more likely to fill the White House with someone not in sympathy with the former President's party and, presumptively, with her policies and with the electoral will of the people. $^{165}$

contingent successor to the presidency).

${ }^{162}$ This might mean that a President will not appoint to the cabinet someone who is not thirty-five years of age or who was not born in the United States. See U.S. CONST. art. II, $\S 1$, cl. 5 ("No Person except a natural born Citizen ... shall be eligible to the Office of President; neither shall any Person be eligible to that Office who shall not have attained to the Age of thirty five Years ...."). For example, both Henry Kissinger, who was Secretary of State to Presidents Nixon and Ford, and Madeline Albright, who was Secretary of State to President Clinton, were not born in the United States and neither would have been eligible to become acting president had $\S 19$ been triggered.

${ }^{163}$ See discussion supra notes 123-34 and accompanying text.

${ }^{164}$ See Truman, supra note 22, at 129-30.

${ }^{165}$ See id. at 129-30. 
Truman perhaps was correct to suggest that Speaker succession better guarantees party continuity than succession by the President Pro Tem, but it does not follow that Speaker succession guarantees party continuity generally. For most of the fifty-plus years that $\S 19$ has been in effect, including all but nine of the last thirty-four years, Truman's assumption about the House of Representatives has been wrong. Divided government and ticket-splitting have, since World War II, become the norm rather than the exception; having a President and a House majority (and Speaker) of different parties is now commonplace. ${ }^{166}$ There almost always would have been a change in party control of the White House had $\S 19$ been invoked, filling the White House with someone not in party sympathy with the former President and not in sympathy with the electoral will expressed by the President's national electoral constituency. As long as the legal and constitutional possibility of divided government exists, $\S 19$ creates the risks of conflicts of interest, manipulation, gamesmanship, shenanigans, and substantial changes in public policy that accompany the possible change of party control in the executive.

Double-vacancy succession perhaps provides additional arguments for those who would amend the Constitution to establish a system of pure party government. ${ }^{167}$ Eliminating divided government and guaranteeing that the Speaker is a Democrat when the President and Vice President are Democrats eliminates the risk of a party change and ensures that any acting president will be, in partisan terms, a suitable successor. Unified government also would eliminate partisan motivations for political gamesmanship under the current version of $\S 19$.

We perhaps could resolve the partisanship problems (but not the substantial separation of powers problems) with legislative succession by placing next in line the House and Senate leaders from the presidential party, whatever legislative offices they may hold. In other words, the Speaker or President Pro Tem would be next in line only when Congress and the White House are controlled by the same party; otherwise, executive power would devolve to the leader of the minority party caucus in the House, then to the holder of that position in the Senate. The problem with this solution is that only the Speaker and the President Pro Tem are required legislative officers under the Constitution. ${ }^{168}$ There is no constitu-

${ }^{166}$ See supra notes 129-34.

${ }^{167}$ See discussion supra notes $142-44$ and accompanying text.

${ }^{168}$ See U.S. CONST. art. I, $\S 2$, cl. 5 ("The House of Representatives shall chuse their Speaker and other Officers...."); id. §3, cl. 5 ("The Senate shall chuse their other Officers, and also a President pro tempore ...."). 
tional requirement that there be formal party caucuses or Minority Leaders, and either house may, at any time, unilaterally eliminate such a position through its power to establish its own rules of operation. ${ }^{169}$ We should be hesitant to place in the statutory line of presidential succession (which is established through Bicameralism and Presentment) a legislative officer whose office is not required or guaranteed by the Constitution and whose office may be eliminated by the singular act of one house without concurrence of the other house or the executive.

The better way to ensure the important structural goal of keeping the White House in the same party hands is to re-establish cabinet succession. Cabinet officers generally will be of the same political party as the President. It is natural that the President, in selecting cabinet officers to whom to delegate a portion of the executive power, will choose people who are in party and policy agreement with her. There generally would be no change in party control of the White House if the Secretary of State ascends to the presidency.

Even if the President selects cabinet officers from a different party in order to create a more ideologically and politically diverse and inclusive administration, she likely will select people from the rival party who are in substantial policy agreement with her. Regardless of party, cabinet officers likely are committed to the same agenda as the former President and likely will continue to pursue that agenda after succession. This perhaps is an advantage of the ideological breadth and non-programmatic nature of American parties-there is more likely to be some agreement across the aisle, such that a President may appoint cabinet members from the opposite party and a change in party control might not mean a radical policy change.

For example, had William Cohen, a Republican serving as Secretary of Defense during the second Clinton administration, succeeded under $\S 19$, there is no reason to believe that he would have departed dramatically from Clinton's policy agenda, particularly with regard to military and foreign affairs. But Cohen, regardless of party affiliation, was Clinton's handpicked policy subordinate, chosen because of his agreement with and commitment to a policy agenda. It is far less likely that a Republican Speaker such as Newt Gingrich would have been in substantial policy agreement with a Democratic former President such as Clinton, suggesting that substantial policy change is more likely under legislative succession.

The import of maintaining party control of the White House does not change because the President's party lost seats (and even a legislative

${ }^{169}$ See id. § 5, cl. 2 ("Each House may determine the Rules of its Proceedings (..."). 
majority) in a mid-term election. That election was an act of the smaller local and state congressional constituencies, rather than the President's national constituency, and neither the President nor her party lost control of the executive branch. ${ }^{170}$ The vote should not be read as a decision to change the party in control of that branch or as the voters' desire to change the party in control of that branch. The President and her party perhaps lost influence and some control over the policy agenda but did not lose the White House. The party therefore should not lose the White House in the event of a double vacancy and the triggering of the succession statute.

Considered individually, political partisanship demands succession by members of the cabinet, rather than succession by a member of Congress. Taken together, partisanship and separation of powers overwhelmingly support a switch to cabinet succession.

\section{Democracy}

\section{Democracy Considered}

Democracy refers to the role of the People in choosing officials and in making political decisions. ${ }^{171}$ Democracy in the selection process can be direct, meaning the federal office holder is chosen by the People, or indirect, meaning the federal office holder is chosen by some individuals, such as state legislators or presidential electors, who themselves have been chosen by the People. The original emphasis was on indirect democracy; direct democracy has increased in import as the federal government has evolved.

From a modern perspective, the Constitution "started out with an incredibly undemocratic electoral process."172 The People were the ultimate sovereign under the Constitution and were the legitimate source of power from whom the Constitutional charter was derived and with whom all power ultimately resided. ${ }^{173}$ The support of a current majority was

${ }^{170}$ See discussion supra notes $131-34$ and accompanying text.

${ }^{171}$ See McWilliams, supra note 15 , at 79 ("Democracy is inseparable from democratic ways of framing and arguing for political choices.").

${ }^{172}$ Mikva, supra note 18 , at 797.

${ }^{173}$ See THE FEDERALIST No. 49, at 281-82 (James Madison) (Clinton Rossiter ed., 1961) (" $[T]$ he people are the only legitimate fountain of power, and it is from them that the constitutional charter, under which the several branches of government hold their power, is derived ...."); see also Berns, supra note 18, at 62 (stating that all Framers agreed that the source of legitimate government was the People); Ceaser, supra note 55, at 174 (stating that the power to form the basic charter of government "lies, in a primitive sense, with the body of the people"); Fitzgerald, supra note 13, at 725 (arguing that the "politically active People... are themselves the single 'absolute and perpetual sovereign' within their political 
perceived as necessary for the effective functioning of the government. ${ }^{174}$ At the same time, most decisions as to the selection of federal office holders were out of popular hands; the sense of the People was to be neither close to the actual officer selected nor particularly frequent. ${ }^{175}$ The Constitution was designed to provide "constitutional space," a distance between the governmentand the People. ${ }^{176}$ That space ordered democracy's passions and rationalized its expressions where policymaking was concerned. ${ }^{177}$ That space necessarily would serve the same purpose where selection is concerned.

Direct democratic selection was limited under the original Constitution, with the House of Representatives being the only department in the federal government chosen by direct popular election. ${ }^{178}$ Even where there was direct democracy, its scope and extent were limited. In elections for the House, the states controlled voter qualifications, often with restrictive and exclusionary rules that could and did vary from state to state. ${ }^{179}$ The national electorate in 1787 comprised only about twenty percent of the population, as most states limited the franchise to white male property owners. ${ }^{180}$ The states also controlled congressional districting, with no

universe"); Hardin, supra note 57, at 93 ("[T] he people have been held to be the source of law.").

${ }^{174}$ See THE FEDERALIST No. 49, at 281-82 (James Madison) (Clinton Rossiter ed., 1961).

${ }^{175}$ See id. at 284.

${ }^{176}$ See Mansfield, supra note 16, at 14-15; see also Josephson \& Ross, supra note 67, at 152 (discussing the Framers' arguments as to the need for a layer between the People and government decision-making); Ross \& Josephson, supra note 115 , at 676 (same).

${ }^{177}$ See Fitzgerald, supra note 13, at 734; see also THE FEDERALIST No. 10, at 49 (James Madison) (Clinton Rossiter ed., 1961) (arguing that a republican, representative form of government is preferable to democracy in controlling factions and passion).

${ }^{178}$ See U.S. CONST. art. I, § 2, cl. 1; THE FEDERALIST No. 52, at 295 (James Madison) (Clinton Rossiter ed., 1961) (arguing that the House should have immediate dependence on and sympathy with the People through frequent elections); see also Mikva, supra note 18, at 797 (arguing that the original system was undemocratic because the People could choose only the House of Representatives); Wechsler, supra note 5, at 546 ("[T] the "grand depository of the democratic principle of the government . ..."') (quoting George Mason in the Convention, 5 ELLIOT's DEBATES 136 (1876)).

${ }^{179}$ See Mikva, supra note 18, at 797; Neuborne, supra note 15, at 1592-93; Wechsler, supra note 5, at 549.

${ }^{180}$ See Mikva, supra note 18, at 797; see also Neuborne, supra note 15, at 1593 (arguing that conceptions of suffrage were extremely limited in 1787); Wechsler, supra note 5, at 549 (describing problems of state contraction of the electorate). 
constitutional guidelines other than that every state have at least one Representative and that the number of Representatives not exceed one for every 30,000 people. ${ }^{181}$ This made possible great discrepancies in district size. ${ }^{182}$

The remainder of the federal government was subject only to indirect democracy, through which the People chose the individuals who in turn chose federal office holders. The Senate was chosen by the state legislatures themselves. ${ }^{183}$ The President was elected by presidential electors chosen specifically and only for the purpose of selecting that office. ${ }^{184}$ The manner of choosing electors was controlled and directed entirely by the legislature of each state; ${ }^{185}$ it could include popular selection but need not do so. ${ }^{186}$

${ }^{181}$ See U.S. CONST. art. I, $\S 2$, cl. 3 (establishing initial House representation, setting a maximum number of representatives based on population, establishing an initial level of representation from each state, and providing that each state should have at least one representative).

${ }^{182}$ See Wechsler, supra note 5, at 550-51 (noting earlier "great discrepancies in district size").

${ }^{183}$ See U.S. CONST. art. I, § 3, cl. 1, amended by U.S. CoNST. amend. XVII, cl. 1; THE FEDERALIST No. 62, at 345 (James Madison) (Clinton Rossiter ed., 1961) (arguing that state selection of senators provided for select appointments and gave the state governments a significant agency in the federal government); see also Bybee, supra note 19, at 511-12 (discussing two competing views of the rationale for state selection of the Senate, including the need to give power to the upper classes of society).

${ }^{184}$ See U.S. CONST. art. II, § 2, cl. 3, amended by U.S. CONST. amend. XII; see also THE FEDERALIST No. 68, at 380 (Alexander Hamilton) (Clinton Rossiter ed., 1961) (arguing that selection of the executive should be left to "men chosen by the people for the special purpose, and at the particular conjuncture"); $i d$. ("A small number of persons, selected by their fellow-citizens from the general mass, will be most likely to possess the information and discernment requisite to so complicated an investigation.").

${ }^{185}$ See U.S. CoNST. art. II, § 1, cl. 2 ("Each State shall appoint, in such Manner as the Legislature thereof may direct, a Number of Electors ...."); Bush v. Gore, 531 U.S. 98, 104 (2000) (per curiam) ("[T] he State legislature's power to select the manner for appointing electors is plenary ...."); McPherson v. Blacker, 146 U.S. 1,29 (1892) ("No question was raised as to the power of the State to appoint, in any mode its legislature saw fit to adopt, and none that a single method, applicable without exception, must be pursued in the absence of an amendment to the Constitution."); see also Josephson \& Ross, supra note 67, at 166 (arguing that the legislative power to select the manner of appointment of electors is plenary and exclusive).

${ }^{186}$ See KURODA, supra note 67, at 15; see also Bush, 531 U.S. at 104 (providing that the "individual citizen has no federal constitutional right to vote for electors for the President of the United States unless and until the state legislature chooses 
Several members of the Constitutional Convention, notably Gouverneur Morris, Robert Morris, James Wilson, and James Madison, advocated direct national popular election of the President. ${ }^{187}$ Such proposals were rejected, based on a fear of direct democracy and a preference for democracy largely remaining indirect. ${ }^{188}$ Many of the Framers feared that direct national democracy, through national popular election, was unworkable, given the size and scope of the national government and the presumed lack of available information about the character and qualifications of candidates that would enable voters to make educated choices. ${ }^{189}$ Some questioned whether a majority could agree on any single candidate for President on the assumption that only two Americans, George Washington and Benjamin Franklin, had sufficient national reputations to gain majority support. ${ }^{190}$ Others thought direct popular election would give the President too much power. ${ }^{191}$

It generally is agreed, at the same time, that the system has become more democratic as it has evolved. The historical trend has been the shrinking of constitutional space, the encroachment of the People on selection processes, and the enhancement of direct (rather than indirect)

a statewide election as the means to implement its power to appoint members of the Electoral College").

187 See HARDAWAY, supra note 14, at 81 (stating that Robert Morris and, initially, Madison proposed popular election); KURODA, supra note 67, at 9 (stating that the most nationalistic members favored direct national election); JACK N. Rakove, ORIGINAL MEANINGS: POlITICS AND IDEAS IN THE MAKING OF THE CONSTITUTION 259 (1996) (stating that Morris's proposal for direct election was supported by Wilson and Madison).

- ${ }^{188}$ See HARDAWAY, supra note 14, at 75 (quoting Elbridge Gerry as stating that "the evils we experience flow from the excess of democracy"); id. at 13 (stating that the proposal for popular election was the one most soundly defeated at the Convention).

${ }^{189}$ See KURODA, supra note 67, at 9 (stating that opponents of direct election suggested that a national election might produce disturbances and riots that would destabilize "the republican experiment"); RAKOVE, supra note 187, at 259 (stating that popular election was rejected because the nation was too large to make it workable); Mikva, supra note 18, at 796 (discussing the Framers' concerns "that the people lacked sufficient knowledge of the character and qualifications of possible candidates to make an intelligent choice"); Ross \& Josephson, supra note 115, at 676 (discussing arguments of Elbridge Gerry against direct election based on concerns that the People would be uninformed and unable to judge candidates).

${ }^{150}$ See KURODA, supra note 67, at 9.

${ }^{191}$ See Althouse, supra note 72, at 995. 
democracy in selection. 192 As one commentator stated, "all the constitutional space was created at America's Founding," and "ever since it has been gradually encroached upon and taken away." 193 The democratizing of the system, the creation of what Akhil Amar called a "modern national democratic ethos,"194 can be seen in several developments.

The first involved formal changes to the constitutional structure, mainly through the Article $\mathrm{V}$ amendment process. The most obvious change is the Seventeenth Amendment, which established direct popular election of Senators. ${ }^{195}$ This change specifically reflected a preference for direct democracy and democratic selection and the People's willingness to shoulder any loss of constitutional federalism in exchange for greater democracy. ${ }^{196}$

Similarly, a series of amendments expanded the franchise, establishing a broad, uniform national electorate. The Constitution now guarantees the franchise to ethnic and racial minorities, women, and eighteen-year-olds ${ }^{197}$

${ }^{192}$ See Berns, supra note 18, at 59 ("The Constitution is more democratic today than in the past and promising (or threatening) to become still more democratic."); Mansfield, supra note 16, at 14 (describing the "long-term, uninterrupted trend toward democratization"); McWilliams, supra note 15, at 79 ("Most Americans would agree that the Constitution has become more democratic with time."); Mikva, supra note 18, at 797 ("We have progressed from those undemocratic beginnings."); Shane, supra note 18, at 548 (describing "the plain democratic trajectory of constitutional development since 1868").

${ }^{193}$ Mansfield, supra note 16 , at 15.

${ }^{194}$ Akhil Reed Amar, A Constitutional Accident Waiting to Happen, 12 CONST. COMMENT. 143, 145 (1995) [hereinafter A. Amar, Accident]; A. Amar, Mandates, supra note 29 , at 391.

${ }^{195}$ See U.S. CoNST. amend. XVII, cl. 1, amending U.S. CONST. art. I, § 3, cl. 1; see also Bybee, supra note 19, at 567-68 (suggesting that the amendment gave the People control over their Senators in the sense of participation in popular elections every six years).

${ }^{196}$ See V. Amar, Indirect Effects, supra note 17, at 1354 (arguing that the Seventeenth Amendment was part of a "broad, albeit imperfectly orchestrated, movement toward popular control"); id. at 1403 ("[T] the extent that election by state legislatures was intended to produce 'better' men in the Senate, the Seventeenth Amendment reflected a reversal in this thinking."); Bybee, supra note 19, at 538 (arguing that the people who supported the amendment "simply preferred democracy to representation and were willing to shoulder the loss to constitutional federalism").

${ }^{197}$ See U.S. CoNST. amend. XV, $\S 1$ (providing that the right to vote may not be denied on account of race, color, or previous condition of servitude); id. at amend. XIX (providing that the right to vote may not be denied on account of sex); 
and prohibits poll taxes in elections for federal offices. ${ }^{198}$ In addition, states voluntarily eliminated property ownership requirements. ${ }^{199}$ The result is an electorate comprising more than seventy-five percent of the population. ${ }^{200}$ Moreover, the Equal Protection Clause of the Fourteenth Amendment commands equal representation for equal numbers of people in the House of Representatives, requiring that House districts be apportioned to achieve population equality. ${ }^{201}$ While the states retain some power to control House districting and voter qualifications, these constitutional changes have limited state discretion in the name of broader popular inclusion in the selection process.

The second development has been the extension of individual civil liberties, as the expansive interpretation and application of the Bill of Rights and the Fourteenth Amendment has come to be associated with, and viewed as a necessary aspect of, a democratic society. ${ }^{202}$ This is especially true for the First Amendment freedom of expression, which in purpose,

id. at amend. XXVI (guaranteeing the vote to citizens who are eighteen years of age or older); see also Mikva, supra note 18, at 797 (describing expansion of the franchise); Neuborne, supra note 15, at 1594-95 (same); Shane, supra note 18, at 548-49 (describing "the plain democratic trajectory of constitutional development since $\left.1868^{\prime \prime}\right)$.

198 See U.S. CONST. amend. XXIV, $\S 1$ (providing that the right to vote in elections for federal offices shall not be abridged or denied "by reason of failure to pay any poll tax or other tax").

${ }^{199}$ See Mikva, supra note 18, at 798.

${ }^{200}$ See id. (" $[W]$ e have come as close to universal suffrage as any country in world history."); Neuborne, supra note 15, at 1595 ("[W] hatever the failings of the body of the 1787 Constitution, the complete modern text, as amended, is suffused with a normative vision of democracy that... guarantees all members of the polity the equal right to participate effectively in the processes of self-governance.").

${ }^{201}$ See Karcher v. Daggett, 462 U.S. 725, 730 (1982) (requiring that House districts "achieve population equality 'as nearly as is practicable") (quoting Wesberry v. Sanders, 376 U.S. 1, 18 (1964)); see also Tushnet, supra note 99, at 156 ("The Court has enforced a rule of strict equality of population in apportionment for the House of Representatives.").

${ }^{202}$ See Morton Horwitz \& Orlando do Campo, When and How the Supreme Court Found Democracy-A Computer Study, 14 QUINNIPIACL. REV. 1,29(1994) ("The central role of democracy in American constitutional law accounts for the surge in the Supreme Court's use of democracy in the last fifty years."); Neuborne, supra note 15, at 1592 (arguing that the "constitutional text reveals a normative vision of democracy"); id. at 1593-94 (arguing that the amendment process, notably the passage and interpretation of the Bill of Rights, helped flesh out a normative conception of democracy in the Constitution). 
function, and operation is linked to democracy and to the effective operation of a democratic political system. ${ }^{203}$ One commentator has argued that the very order in which the several rights are enumerated in the text of the First Amendment "mirrors the life cycle of a democratic idea, moving from the interior recesses of individual conscience, to discussion and collective action, and culminating in the formal give and take of politics."204 The Court and commentators have shown particular solicitude for speech relating to the electoral and political processes, given the import and necessity of such speech to the operation of a democratic system of government. ${ }^{205}$

The third development has been the establishment, however informally, of the populist presidency. As Steven Calabresi has argued, the President is viewed as a nationwide popularly elected official, representing a distinct, openly national, majority electoral constituency. ${ }^{206}$ The President runs on

${ }^{203}$ See MARTIN H. REDISH, FREEDOM OF EXPRESSION: A CRITICAL ANALYSIS 21-22 (1984) (arguing that democracy and free expression foster the same values and that free expression must be broadly protected in any democratic political system); Edmond Cahn, Justice Black and First Amendment "Absolutes": A Public Interview, 37 N.Y.U. L. REV. 549, 559 (1962) (interview with Justice Black) (Justice Black agreeing that a basic purpose of the First Amendment was protection for political speech); Alexander Meiklejohn, The First Amendment is an Absolute, 1961 SUP. CT. REV. 245, 259 (arguing that speech that has no relation to the business of governing is unprotected by the First Amendment).

${ }^{204}$ Neuborne, supra note 15, at 1594; see U.S. CONST. amend. I ("Congress shall make no law respecting an establishment of religion, or prohibiting the free exercise thereof; or abridging the freedom of speech, or of the press; or the right of the people peaceably to assemble, and to petition the Government for a redress of grievances.").

${ }^{205}$ See McIntyre v. Ohio Elections Comm'n, 514 U.S. 334, 346 (1995) ("[D]ebate on the qualifications of candidates are integral to the operation of the system of government established by our Constitution."); Mills v. Alabama, 384 U.S. 214, 218-19 (1966) (holding that protection of the First Amendment includes discussions of candidates, structures and forms of government, the manner in which government is operated or should be operated, and all such matters relating to political processes); see also REDISH, supra note 203, at 22 (emphasizing the importance of protecting speech to aid in making political judgments); Meiklejohn, supra note 203, at 255 (arguing that the First Amendment protects the freedom of activities of thought and communication by which we govern, particularly in casting a ballot).

${ }^{206}$ See Calabresi, Some Normative Arguments, supra note 60, at 59 (arguing that the President is accountable to a national voting electorate and no one else); Calabresi, Political Parties, supra note 16, at 1508 ("The President is electorally responsible to the nation as a whole."); Calabresi, Presidential Succession, supra 
a national agenda and is national in her electoral and policy outlook. ${ }^{207}$ As Herbert Wechsler put it, the President has become "the main repository of 'national spirit' in the central government."'208

It is true, of course, that the President formally is selected according to the mechanisms of the Electoral College, regardless of the outcome of the nationwide popular vote. ${ }^{209}$ And as the Supreme Court put it most bluntly, there is no federal constitutional right for the People to vote even for electors, ${ }^{210}$ much less to vote for President. The Electoral College process is widely criticized as undemocratic and anachronistic. ${ }^{211}$ Such criticisms certainly will increase in the wake of the 2000 election, in which President George W. Bush lost the nationwide popular vote by more than 500,000 votes and received 271 electoral votes, one more than needed to prevail, and only after the confused and contested popular election in the state of Florida and the controversial decision of the United States Supreme Court to halt recounts in that state. ${ }^{212}$

note 50, at 172 ("[T]he President and the Vice President are the representatives of a distinct national majority electoral coalition."); Calabresi \& Larsen, supra note 34, at 1093 (discussing the President's (and Vice President's) national constituency); see also Fitzgerald, supra note 13, at 754 (arguing that the President is "politically dependent on a national People").

${ }^{207}$ See Wechsler, supra note 5, at 552 (arguing that the President presents programs that reflect the needs of the entire nation, thereby balancing the localism of Congress).

208 Id. at 557-58.

${ }^{209}$ See U.S. CONST. art. II, § 1, cl. 2-3, amended by U.S. CONST. amend. XII.

${ }^{210}$ See Bush v. Gore, 531 U.S. 98, 104 (2000) (per curiam) (stating that the "individual citizen has no federal constitutional right to vote for electors for the President of the United States unless and until the state legislature chooses a statewide election as the means to implement its power to appoint members of the Electoral College").

${ }^{211}$ See A. Amar, Accident, supra note 194, at 143 ("Our system of selecting Presidents is a constitutional accident waiting to happen."); A. Amar, Mandates, supra note 29, at 390 (arguing that none of the arguments for the Electoral College works today); Mikva, supra note 18, at 795 (arguing that the Constitution sought to protect presidential selection from direct democracy and majority votes); Victor Williams \& Alison M. Macdonald, Rethinking Article II, Section 1 and its Twelfth Amendment Restatement: Challenging Our Nation's Malapportioned, Undemocratic Presidential Election Systems, 77 MARQ. L. REV. 201, 203-04 (1994) (discussing "the nation's significantly malapportioned electoral college system").

${ }^{212}$ See Bush, 531 U.S. at 100-04 (discussing legal challenges to the outcome of the popular vote in the state of Florida and attempts to order recounts of votes in several counties); Bush v. Palm Beach County Canvassing Bd., 531 U.S. 70, 73-76 
Sub-constitutional developments in the actual operation of the Electoral College have created a selection system in which the President, in practice, is popularly elected, albeit on a state-by-state, as opposed to truly nationwide, basis. ${ }^{213}$ All of the states have adopted, pursuant to their constitutional discretion, popular election as the means of choosing presidential electors, furthering the democratic principle. ${ }^{214}$ Ballots generally list the names of the presidential and vice presidential candidates, not the names of the electors who will cast the true votes for President; a vote cast for a designated presidential (and vice presidential) candidate is deemed a vote for that party's slate of nominees to the Electoral College. ${ }^{215}$

States also retain the power to control (or permit control of) how electors actually cast their presidential votes; electors in more than half the states, once chosen, are obligated to vote consistently with the results of the state's popular vote. ${ }^{216}$ States generally do this either by requiring electors to vote for the presidential candidate of the party that appointed her or by

(2001) (per curiam)(same). For commentary on the Supreme Court's decisions and the 2000 presidential election, see generally SAMUEL ISSACHAROFF ET AL., WHEN ELECTIONS GO BAD: THE LAW OF DEMOCRACY AND THE PRESIDENTIAL ELECTION OF 2000 (2001); RICHARD A. POSNER, BREAKING THE DEADLOCK: THE 2000 ELECTION, THE CONSTITUTION, AND THE COURTS (2001).

${ }^{213}$ See A. Amar, Accident, supra note 194, at 144 (arguing that direct election is our de facto scheme today); Casper, supra note 11, at 178 (arguing that the Electoral College has been redirected into a mechanism for the popular election of the President).

${ }^{214}$ See Bush, 531 U.S. at 104 ("History has now favored the voter, and in each of the several States the citizens themselves vote for Presidential electors."); McPherson v. Blacker, 146 U.S. 1, 32-33 (1892) (stating that after 1832, the electors in all states, except South Carolina, were chosen by general ticket popular vote); HARDAWAY, supra note 14, at 148 (stating that, with a few exceptions, all of the states by the 1830s had provided for appointment of electors by popular election); Amar \& Amar, President Quayle?, supra note 114, at 919 (stating that by the 1820 s popular elections to choose presidential electors were commonplace); Josephson \& Ross, supra note 67, at 160-61 (stating that all states provide for a popular vote for electors, with all but two providing that all electors go to the winner of the plurality of the statewide popular vote).

${ }^{215}$ See Ray v. Blair, 343 U.S. 214, 229 (1952) (stating that states allow a vote for the presidential candidate of the national party to be counted as a vote for his party's nominees for the electoral college); Amar \& Amar, President Quayle?, supra note 114 , at $925-26 \& \mathrm{n} .51$ (stating that the names of electors are generally not printed on the ballot).

${ }_{216}$ See Amar \& Amar, President Quayle?, supra note 114, at 919; Ross \& Josephson, supra note 115, at 690 . 
permitting the parties to obtain pledges from each elector to vote for her party's candidate. ${ }^{217}$ This reduces or eliminates the likelihood of a faithless elector voting for a candidate other than the one to whom she committed and who won the popular vote in that state. ${ }^{218}$

The perception of individual voters is that they cast a popular vote for President and that the President will be the winner of a popular plurality; the Electoral College is merely the "shadowy institution" that ratifies the popular choice. ${ }^{219}$ After the Bush-Gore election, in which the winner of the national popular election did not, in fact, win the presidency, this perception has been destroyed on the national level.

That perception remains accurate when viewed on a state-by-state basis. We may better understand the President's electoral constituency less as a national constituency than as a coalition of state electoral constituencies, weighted according to each state's congressional representation, including its population. ${ }^{220} \mathrm{~A}$ candidate for President stands for election before all of these state electorates simultaneously, putting forward a nationwide agenda. In practice, the winner of a plurality of the popular vote in a given state will win all of the electoral votes from that state. The winner of a plurality of the popular votes of some coalition of states totaling one more than half of the electoral votes, based on total congressional representation, will become President.

In other words, the President must win a weighted majority of state popular elections. Putting aside the obvious procedural problems and confusion in the 2000 presidential election in Florida, George W. Bush, who stood as a candidate in all fifty-one jurisdictions, did just that. He was

${ }^{217}$ See Ross \& Josephson, supra note 115, at 690-91 \& nn.132-34 (describing three different ways of requiring electors to vote for candidate of one party); see also Ray, 343 U.S. at 231 (upholding state law permitting a party to obtain a pledge from electors as to how they will cast their votes).

${ }^{218}$ See Berns, supra note 18, at 59 ("[E]xcept for an occasional maverick eager to call attention to himself at no cost to anyone else, [electors] have long since given up their nominal independence."); see also HARDAWAY, supra note 14, at 147 (stating that only seven such unfaithful votes have been cast in the past 150 years).

${ }^{219}$ See Calabresi, Presidential Succession, supra note 50, at 171; Tushnet, supra note 99, at 149 (arguing that the Electoral College "rapidly became merely the forum for ratifying the voters' choice").

${ }^{220}$ See HARDAWAY, supra note 14, at 13 (arguing that the Electoral College establishes majority support through the conduit of the states); Althouse, supra note 72, at 1012 (arguing that the People understand that they vote in "fifty-one concurrent elections that would be aggregated"). 
the declared winner of popular elections in thirty states, with a weight of 271 electoral votes - a majority; the Electoral College vote reflected the weighted outcome of those thirty popular elections. ${ }^{221}$

One possible change to the procedures for selecting the President, suggested first by Thomas Jefferson in 1801 and later by Andrew Jackson in 1829 , would formally establish the current informal system. It would eliminate electors and choose the President directly through fifty-one concurrent statewide popular elections; the winner of the popular vote in each state automatically would receive a number of "votes" equal to that state's total congressional representation, and the President would be the winner of a majority (the same majority of 270 votes as in the current system) of those votes. ${ }^{222}$ This procedure truly could be described as weighted state-by-state popular election, the goal of which is to win popular pluralities in the right coalition or aggregation of states. The difference is the elimination of the electors, the Electoral College, and the special, secret Electoral College vote that creates the undemocratic quality of the current procedure. ${ }^{223}$ The intermediary would be eliminated from the selection procedure - the constitutional space further reduced. ${ }^{224}$

This plan most obviously eliminates the risk of a faithless elector not voting for the candidate to whom she has pledged and guarantees that the outcome as expressed in the statewide popular vote will be reflected in that state's electoral vote. ${ }^{225}$ The faithless elector is a rarity, however, given that most states now significantly cabin or eliminate any real elector discretion. ${ }^{226}$ Otherwise, this new procedure does not substantially alter the

${ }^{221}$ Whether or not Bush in fact did win, or should have been declared the winner of, the popular election in Florida is beyond the scope of this Article.

${ }^{222}$ See Andrew Jackson, First Annual Message to Congress, Dec. 8, 1829, in THE STATESMANSHIP OF ANDREW JACKSON AS TOLD IN HIS WRITINGS AND SPEECHES 43-44 (Francis Newton Thorpe ed., 1909) (arguing for establishing popular election, but with each state retaining its relative power and influence); see also HARDAWAY, supra note 14, at 147-48 (describing the "Automatic Plan" for choosing the President, in which the actual office of elector would be eliminated and electoral votes automatically would be awarded as under the current system); Althouse, supra note 72 , at 994 \& n.3 (same).

${ }^{223}$ See Mikva, supra note 18, at 799 (arguing that the Electoral College is undemocratic "because it is secret").

224 See Mansfield, supra note 16, at 15 (describing the reduction of "constitutional space" between the People and elected officials as the system has developed).

${ }^{225}$ See HARDAWAY, supra note 14, at 147.

${ }^{226}$ See discussion supra notes 216-19 and accompanying text. 
way in which the President is selected. ${ }^{227}$ It also will be unsatisfying to those who want a truly nationally elected President and who object to any procedure that potentially might elect a President who did not win at least a plurality of a straight nationwide popular vote. ${ }^{228}$ Assuming, however, that a constitutional amendment establishing a true nationwide popular election is politically unlikely even after the 2000 election, ${ }^{229}$ Jackson's procedure should have some appeal after the 2000 election, because removing electors and the Electoral College from the mix would eliminate some of the troubling issues that arose in the Florida election.

First, this procedure eliminates the partisan gamesmanship of the Florida legislature, which, in the midst of the contests, recounts, and lawsuits, initiated proceedings to appoint its own slate of electors, committed to Republican George W. Bush, the preferred candidate of the legislative majority and of Florida Governor Jeb Bush, George Bush's brother. ${ }^{230}$ That appointment would have been made without regard to the ultimate result of the state's popular vote and before that ultimate result even had been determined upon completion of the recounts.

${ }^{227}$ See HARDAWAY, supra note 14 , at 147 (" $[\mathrm{]}] \mathrm{t}$ is the very modesty of this plan that makes it unlikely to be adopted."); Althouse, supra note 72, at 1011 (discussing the argument that the faithless elector problem is too "minuscule" to warrant a constitutional amendment).

${ }^{228}$ A. Amar, Accident, supra note 194, at 145 (discussing concern for the "dreaded specter of a clear popular loser becoming the electoral college winner"). But see Althouse, supra note 72, at 1012 (arguing that the loss of the national popular vote by the electoral vote winner is the result of the "decision to campaign efficiently under the requirements of the electoral college plan," such as by not culling for extra votes in states the candidate is certain either to win or to lose).

${ }^{229}$ See HARDAWAY, supranote 14, at 163 (discussing past failures to amend the Constitution to establish direct election); Wechsler, supra note 5 , at 554 ("Whatever may be said in principle for simple popular election, it would so diminish the political importance of the states of small electorates that it has no hope of adoption."); id. at 558 (suggesting that the mode of presidential selection, while national, should also make the President responsive to local values). But see A. Amar, Accident, supra note 194, at 144 (arguing that direct election has been made possible, given the changes in the political system and the nation); see also Althouse, supra note 72 , at 993 \& n.2 (describing a joint resolution before Congress calling for a Constitutional amendment to establish direct nationwide popular election, with a runoff between the top two vote-getters twenty-one days later if no candidate receives a forty percent plurality).

${ }^{230}$ See Shane, supra note 18, at 549. These legislative efforts ceased following the Supreme Court's second Bush decision and after Albert Gore conceded the election. See id. 
There perhaps is a question of whether the Florida legislature had the constitutional power to change, mid-election, the manner of appointing electors from popular selection to legislative appointment. The Constitution gives the states plenary power to determine the manner of appointing electors ${ }^{231}$ and nothing suggests any limitation on that power, including any limitation on the time or context in which a legislature may determine or change that manner of appointment. While the Fourteenth Amendment does establish the constitutional principle of "one person, one vote,"232 the principle means only that, where there is an established right to vote for a particular office, every voter must have an equal number of votes and an equal electoral voice. ${ }^{233}$ However, the Fourteenth Amendment does not affirmatively create a right to vote for President or for presidential electors, nor does it limit the power of a state to grant, not grant, or withdraw such a right. The Supreme Court did not discuss this aspect of the election controversy in Bush, but it unquestionably was aware of the legislature's actions. Moreover, the majority's absolute language- the State "can take back the power to appoint electors" would have approved of such a mid-stream change in the manner of appointment.

It perhaps could be argued that the establishment of the democratic ethos, the expanded franchise, and the rights of individual voters in the modern constitutional order should constrain the power of a state legislature to deny the People a voice in choosing presidential electors, as the Florida legislature attempted to do. However, this is an argument, albeit an accurate one, from the democratic principle and from what the state legislature should do. It does not go to what the states may do as a matter of constitutional power. Had the Florida legislature followed through on its plan, such action would have been undemocratic, entirely inconsistent with

${ }^{231}$ See U.S. CONST. art. II, $\S 1, \mathrm{cl} .2$ (providing that each state legislature may determine the manner of appointing electors).

${ }^{232}$ See Reynolds v. Sims, 377 U.S. 533, 565 (1964) (discussing the Equal Protection Clause's requirement of one person, one vote).

${ }^{233}$ See Bush v. Gore, 531 U.S. 98, 104-05 (2000) (per curiam) ("Having once granted the right to vote on equal terms, the State may not ... value one person's vote over that of another."); Harper v. Virginia Bd. of Elecs., 383 U.S. 663, 665 (1966) ("[O]nce the franchise is granted to the electorate, lines may not be drawn which are inconsistent with the Equal Protection Clause of the Fourteenth Amendment.").

${ }^{234}$ Bush, 531 U.S. at 104; see also McPherson v. Blacker, 146 U.S. 1, 35 (1892) ("[T] here is no doubt of the right of the legislature to resume the power at any time, for it can neither be taken away nor abdicated."). 
the independent principle of democracy - but it would have been constitutional. 235

Under a system of true weighted state-by-state popular election, only the will of the People of each state, as expressed in the statewide popular vote certified by the state in a largely ministerial act, based on a popular election permitted to run to its conclusion, is determinative. There would be no electors for the state legislature to appoint and no opportunity for the legislature to end-run the popular vote and put forward its own preferred slate of electors. The state's role would be identical to its role in House and Senate elections: controlling the manner of running the election, establishing procedural mechanisms for supervising voters, and counting (and recounting) votes, without power ever to dictate or influence the outcome. $^{236}$

Second, removing electors eliminates the need for the multiple early deadlines for the naming and meeting of electors and for the counting of electoral votes on which the Supreme Court relied in halting all recounts in the 2000 Florida presidential election. ${ }^{237}$ There would be no meeting date for electors; ${ }^{238}$ there would be no need for the "safe harbor" provision that makes a slate of electors conclusive if certified by a particular date; ${ }^{239}$ and there would be no need for procedures by which Congress could contest particular electoral votes. ${ }^{240}$ The new system could rely on a single date-perhaps on or about January 5, when the new Congress convenes,

${ }^{235}$ But see Shane, supra note 18, at 549 ("It is unthinkable, against this history of constitutional development, that a state legislature should still be deemed authorized to usurp the people's role in choosing presidential electors.").

${ }^{236} \mathrm{See}$ U.S. CONST. art. I, § 4, cl. 1 ("The Times, Places and Manner of holding Elections for Senators and Representatives, shall be prescribed in each State by the Legislature thereof ...."); Cook v. Gralike, 531 U.S. 510, 525-26 (2001) (striking down a state provision that was not a procedural mechanism, but rather an attempt to dictate electoral outcomes).

${ }^{237}$ See Bush, 531 U.S. at 110 (holding that a constitutionally consistent recount could not be performed without substantial work prior to the December 12th date for conclusive selection of electors that had been incorporated into state law); id. at 121-22 (Rehnquist, C.J., concurring) (stating that a recount would jeopardize the state "legislative wish" to take advantage of the safe harbor of 3 U.S.C. $\$ 5$ ).

${ }^{238}$ See 3 U.S.C. $\$ 7$ (1994) (providing that electors meet on the Monday after the second Wednesday in December following their appointment).

${ }^{239}$ See id. $\S 5$ (providing that if electors are chosen by established state procedures at least six days before the time for the meeting of the electors, that slate and its votes are conclusive).

${ }^{240}$ See id. $\S \S 15-18$. 
two weeks prior to the January 20 Inauguration ${ }^{241}$-by which each state must certify and send to Congress the results of its popular election.

This allows ample time, almost two months, for challenges, contests, and recounts of the popular votes, in accordance with state laws and procedures, without the need for shorter dates that could halt any recounts or vote-counting procedures. The determination of the popular winner would be a question of state law determined according to the ordinary workings of state legislation and judicial decisionmaking, ${ }^{242}$ subject to Equal Protection and other constitutional limitations on the voting process; Congress would be required to accept the certification from each state.

Had this selection procedure been in place during the 2000 election, the Supreme Court's decision in Bush on December 12 that a uniform recount procedure was necessary to avoid equal protection concerns would not have ended the election. ${ }^{243}$ There would have been no December 12 safe harbor deadline on which the Court would rely. Rather, Florida would have had approximately one additional month to correct any constitutional problems in the recount procedures, to carry out the recount, and to permit the election process to conclude and produce a popular winner, who automatically would have received the state's 25 electoral votes.

\section{Democracy and Succession}

The democratic principle is the only possible basis to support the current version of $\S 19 .{ }^{244}$ It was the explicit focus of President Truman and Congress. In Truman's view, the presidency should be filled by an elective

${ }^{241}$ See U.S. CoNST. amend. XX, § 1.

${ }^{242}$ See Bush, 513 U.S. at 123-24 (Stevens, J., dissenting) (arguing that state law relating to presidential elections includes judicial review of legislative actions under the state constitution).

${ }^{243}$ See id. at 533 (holding that a recount could not be conducted in compliance with constitutional requirements without additional work, but that such election could not be carried out within the time frames of the safe-harbor provision of 3 U.S.C. $\$ 5$ incorporated into Florida law). But see id. at 545 (Souter, J., dissenting) ("I see no warrant for this Court to assume that Florida could not possibly comply with this requirement before the date set for the meeting of electors, December 18."); id. at 558 (Breyer, J., dissenting) (arguing for "permitting the Florida recount to continue under uniform standards").

${ }^{244}$ See Calabresi, Presidential Succession, supra note 50, at 174 (" $[D]$ esire for a democratically elected President is the only good argument for placing legislative officers in the line of presidential succession."). 
officer, someone who has stood for popular election at some level. ${ }^{245} \mathrm{He}$ believed that the Speaker could best be said to stem from the People since she stands for election every two years as a member of the House of Representatives and is placed in the speakership by a majority of the members of the House, themselves similarly elected. ${ }^{246}$ Truman relied on the common notion of the House of Representatives as the most democratic branch of the federal government, having the most immediate dependence and intimate sympathy with the People. ${ }^{247}$ Therefore, he concluded that the leader of the House should be the acting president in the emergency that would create a double vacancy and trigger operation of the statute. Congress agreed, although with some debate as to whether the House or Senate was the more democratic house of the legislative branch. ${ }^{248}$

Closer examination shows that calling Speaker succession the most democratic approach elevates form over substance. First, the Constitution does not, in fact, require that the Speaker of the House actually be an elected member of that body. ${ }^{249}$ Common practice is that she is; each House party caucus nominates and votes for its leader as Speaker and whichever party holds the majority will place its leader in the speakership. However, any arguments as to the democratic quality of the Speaker as potential presidential successor hinge on an assumption that is not constitutionally mandated.

On a national level, it is counter-intuitive to call a member of the House of Representatives the most democratic official, given the relatively small number of people who comprise the constituency that selects an individual Representative. Members of Congress represent state and local constituencies; they run on local concerns and programs and with a more local electoral focus, emphasizing what they can and will do for that state and

${ }^{245}$ See Truman, supra note 22, at 129.

${ }^{246}$ See id.

${ }^{247}$ See THE FEDERALIST No. 52, at 295 (James Madison) (Clinton Rossiter ed., 1961) ("[I]t is particularly essential that the [House] should have an immediate dependence on, and an intimate sympathy with, the people."); Wechsler, supra note 5 , at 546.

${ }^{248}$ See Brown \& Cinquegrana, supra note 1, at 1427-28 ("The Senate agreed with President Truman's argument that it was better to place elected officials, rather than appointed Cabinet members, at the head of the line of succession."); id. at $1429-30$ (describing Senate debates on this point).

${ }^{249}$ See U.S. CONST. art. I, $\S 2$, cl. 5 (providing only that the "House of Representatives shall chuse their Speaker," with no details as to qualifications); see also Brown \& Cinquegrana, supra note 1, at 1429 (discussing congressional comments over Truman's bill that made this point). 
that district and how they can protect these local interests in Congress. ${ }^{250}$ In choosing individual candidates in House districts, voters likely do not consider what their vote will do for party balance in the House or Senate or how it affects who becomes Speaker or President Pro Tem. The support of the Vermont voters for Senator Jim Jeffords's defection from the Republican Party in June 2001 illustrates the point. Jeffords's decision to become an independent, with its consequent transfer of Senate control to the Democrats, ${ }^{251}$ met with general approval from his constituents, with polls showing that sixty-five percent of Vermont voters supported his switch. This suggests that those who voted for Jeffords when he ran for his Senate seat as a Republican were not particularly focused on his party affiliation or on which party would control the Senate and who would be President Pro Tem (and in the line of presidential succession).

This perhaps was not true during the Newt Gingrich era from 19941998, when Gingrich, as Republican Speaker of the House, arguably was on voters' minds in every House race. Voters in each congressional district were aware that Gingrich would be Speaker should the Republicans control the House and that fact was a focal issue in many of these elections. However, Gingrich in many ways was a true parliamentary-style opposition leader to President Clinton, a shadow President leading the party out of executive power, representing his own national constituency, and promoting his own national policy agenda mirroring that of the President.

${ }^{250}$ See Amar \& Amar, Succession, supra note 21, at 130 (discussing the "narrow, local strategies by which Congressmen secure election in their states and districts, with promises of porkand parks"); Calabresi, Political Parties, supranote 16, at 1507 (arguing that Senators represent states and Representatives represent single-member geographic districts); Calabresi, Presidential Succession, supranote 50, at 172 (describing "congressional devotion to state and local interests"); Fitzgerald, supra note 13, at 749 (arguing that Senate members focus on state interests and House members focus more on local interests); see also discussion supra notes 57-61 and accompanying text.

${ }^{251}$ At the beginning of the 107th Congress in January 2001, the Senate was evenly divided between the two major parties; Republican Vice President Dick Cheney cast the deciding organizational vote in making the Republicans the majority party in that house. See U.S. CONST. art. I, $\S 3, \mathrm{cl} .4$ (providing that the Vice President is President of the Senate and votes in the event of a tie). In becoming an independent, Jeffords threw his support behind the Democratic leadership for organizational purposes, giving the Democrats a 51-49 advantage and making Sen. Tom Daschle (S.D.) the Majority Leader and Sen. Robert Byrd (W. Va.) President Pro Tem. See generally JAMESM.JEFFORDS, MYDECLARATION OF INDEPENDENCE (2001). 
The same cannot be said for Dennis Hastert, the Republican Speaker during the last two years of the Clinton presidency, nor for Tip O'Neill when he was Democratic Speaker during the Reagan presidency (although it arguably was more true for O'Neill than for Hastert). The point is even less valid with regard to succession by the President Pro Tem, who generally is not the leader of the Senate majority caucus and does not control either the Senate's legislative agenda or the party's agenda-that power rests with the Majority Leader, pursuant to Senate practice. The President Pro Tem merely is the senior-most member of the majority party. It is unlikely that individual voters in Senate elections in 2000 gave any real consideration to whether Republican Strom Thurmond or Democrat Robert Byrd would be President Pro Tem as a result of their vote in that individual race.

This contrasts with the development of the populist presidency and the view of the President as a nationally and popularly elected official representing a national constituency (or at least a coalition of a weighted majority of state constituencies). ${ }^{252}$ Even a "national minority" President such as George W. Bush stood for election in all fifty-one voting jurisdictions, ran with a national policy and electoral agenda, received more than fifty million votes nationwide, and won a weighted majority of state popular elections, indicating some broad national public support. Voters know that the President will appoint cabinet and other executive officers to help her carry out the executive power; in fact, speculation as to whom a candidate might appoint to key executive branch positions often is an issue during the election and is used to evaluate that candidate. Cabinet officers, having been hand-selected by the President to help execute the national policy agenda that won national electoral approval, can be said to represent that same national electoral constituency. ${ }^{253}$

Both the Speaker and members of the cabinet gain their nationwide democratic legitimacy from the same source: approval by one house of Congress. The Speaker is placed in that legislative office by a majority of the House of Representatives (usually along a straight party-line vote), a point Truman emphasized in arguing for speaker succession. ${ }^{254}$ Cabinet

${ }^{232}$ See discussion supra notes 206-21 and accompanying text.

${ }^{253}$ See Calabresi, Presidential Succession, supra note 50, at 173 ("[S]enior members of the President's cabinet represent the same electoral coalition that put him into office....").

${ }^{254}$ See Truman, supra note 22, at 129 ("The Speaker of the House of Representatives, who is elected in his own district, is also elected to be the presiding officer of the House by a vote of all the Representatives of all the people of the country."). 
officers must be confirmed by a majority of the Senate, a vote less along party lines, more deferential to the President and the nominee, and suggesting broader support within Congress. ${ }^{255}$ Given that the House and Senate both are popularly elected, these approval procedures, although by different houses representing somewhat different constituencies, are functionally equivalent.

The difference between the Speaker and the Secretary of State is how each one came before that house of Congress for approval. The Speaker (assuming that the practice continues that she be a member of the House) is elected by a majority of the voters in her district to represent their interests in the House. The Secretary of State (and the rest of the cabinet) did not stand for election and never received any popular votes from any constituency, but was appointed to serve by the President, who was elected by that nationwide coalition of state voters.

Ultimately, the difference between the Speaker and Secretary of State is approximately 188,000 votes in one congressional district. That is the number of votes, representing seventy-five percent of the total cast in the district, that Speaker Dennis Hastert received from his congressional district in Illinois in November 2000. It is difficult to argue that 188,000 votes in one of 435 congressional districts makes the Speaker significantly more democratic on a national level, for purposes of presidential succession, than the hand-picked policy subordinate of a President who stood for popular election in all fifty-one jurisdictions and won a weighted majority of those statewide races.

Consider again September 11 and suppose that the terrorists had succeeded in killing both President Bush and Vice President Cheney. Secretary of State Powell would have been more knowledgeable of the military and international landscape and better able to lead and guide the ensuing military, political, and diplomatic action (with which he was involved in any event). Moreover, given Powell's national reputation and his position as the President's hand-picked foreign policy architect, he would have been better able to reassure and lead the People and the nation through the ensuing crisis.

Powell would have enjoyed great nationwide public confidence and support in this role, likely more than would Speaker Hastert or any

${ }^{255}$ See THE FEDERALIST No. 76, at 425 (Alexander Hamilton)(Clinton Rossiter ed., 1961) (emphasizing Senate power of confirmation as a check upon a spirit of favoritism and a source of stability in administration); Calabresi, Presidential Succession, supra note 50, at 173 (arguing that Senate confirmation primarily protects against extremism in executive appointments); see also discussion supra notes 64-66 and accompanying text. 
individual member of Congress. This would be due, in part, to the uniquely high national profile and reputation that Powell would bring to the table as a viable presidential candidate in his own right; this is something that most cabinet officers will not necessarily possess. However, this public support also derives from the connection between Powell and the nationally popularly elected President-the "apostolic legitimacy" that Powell retains by virtue of his appointment by the duly elected President to assist in representing the national constituency of the People. ${ }^{256}$ The nation would be better able to rally behind a successor specifically chosen by the populist President than behind the ordinary, individual Congressman, chosen by the voters of one district, who has risen to the top of the party's legislative caucus.

In support of the new $\S 19$, Truman suggested that it would be inconsistent with the democratic principle for the President to appoint his own successor, as Truman was doing in nominating George Marshall as Secretary of State in $1945 .^{257}$ This argument fails for two reasons.

First, as a practical matter, the President already appoints an immediate potential successor by hand-selecting a running mate, the person who will be Vice President, immediate successor, and heir apparent - the person who will be the proverbial "one heart beat away" from the presidency. In fact, the choice of running mate often is regarded as a presidential candidate's first decision and a first test of her decision making abilities.

It is true that the Vice President is, in some sense, elected, campaigning as part of the ticket with the presidential candidate and receiving Electoral College votes cast specifically for that office. ${ }^{258}$ Under state electoral laws, however, voters cast ballots for a slate of electors pledged to a complete party ticket of President and Vice President. ${ }^{259}$ A voter cannot split her executive branch ticket, cannot vote for a presidential candidate (or electors committed to the presidential candidate) of one party and vice presidential candidate (or electors committed) of another, even if she would prefer to vote that way. ${ }^{260}$ There is no separate popular vote or individual decision for Vice President; a vote for a presidential candidate is an automatic vote

${ }^{256}$ See Amar \& Amar, Succession, supra note 21, at 131.

${ }^{257}$ See Truman, supra note 22, at 129; see also discussion supra notes $42-47$ and accompanying text.

${ }^{258}$ See U.S. CONST. amend. XII (providing for the casting of distinct Electoral College ballots for Vice President).

${ }^{259}$ See Amar \& Amar, President Quayle?, supra note 114, at 925.

${ }^{260}$ See id. at 926; see also id. at 916 (stating that in 1988, many voters would have preferred to vote for Republican presidential candidate George H.W. Bush and Democratic vice presidential candidate Lloyd Bentsen). 
for that candidate's chosen running mate. The real popular decision is for the President; the chosen running mate and hand-picked successor necessarily comes along with the President, just as appointed cabinet officers come along with the President.

Moreover, the same electors who vote for President also vote for Vice President, and they are committed and bound to vote for a particular party for both offices. ${ }^{261}$ There is virtually no chance of an elector splitting her ticket and voting for a vice presidential candidate different than the one hand-selected by the presidential candidate for whom that elector already voted.

Second, to the extent Truman's argument about the undemocratic quality of appointing one's own successor ever was correct, it no longer is in the wake of the Twenty-Fifth Amendment. ${ }^{262}$ Ratified in 1967, twenty years after the passage of $\S 19$, the Amendment gives the President the express constitutional power to appoint, with approval by both houses of Congress, a new Vice President to fill a vacancy in that office. ${ }^{263}$ In other words, the Constitution now recognizes the legitimacy of the President appointing her own potential successor. If it is legitimate for an executive to appoint, with congressional approval, her immediate successor in the Vice President, it is equally legitimate and appropriate for a cabinet officer, who would be a more remote potential successor.

At some level there is no difference between a hand-picked Vice President and a hand-picked cabinet officer. The modern Vice President is, in practice, an additional member of the President's cabinet, selected for that post, just as is the Secretary of State, to help the President carry out the executive power. ${ }^{264}$ Cabinet succession "simply extends this modern model of handpicked succession to the next level of contingency."265

The constitutional legitimacy of the presidential appointment power imparts democratic legitimacy on officials appointed pursuant to that

${ }^{261}$ See discussion supra notes 216-18 and accompanying text.

${ }^{262}$ For a discussion of the connections and inconsistencies between the TwentyFifth Amendment and $\S 19$, see generally Brown \& Cinquegrana, supra note 1 .

${ }^{263}$ See U.S. CONST. amend. XXV, \& 2 ("Whenever there is a vacancy in the office of the Vice President, the President shall nominate a Vice President who shall take office upon confirmation by a majority vote of both Houses of Congress.").

${ }^{264}$ See Manning, supra note 50, at 148 ('Nowadays, we think of the Vice President as the President's hand-picked running mate and a member of the President's Administration.").

${ }^{265}$ Amar \& Amar, Succession, supra note 21, at 131; see id. (suggesting the possibility of the special cabinet position of "First Secretary," nominated and confirmed expressly as a contingent successor). 
power. There were no real concerns about democratic legitimacy in Richard Nixon's appointment of Gerald Ford as Vice President in 1973, in Ford's succession to the presidency upon Nixon's resignation in 1974, or in President Ford's appointment of Nelson Rockefeller as Vice President in 1974. The fact that both appointments followed orderly constitutional processes ensured, at least for a time, the democratic legitimacy of both officials. ${ }^{266}$ The same should hold true for a cabinet officer pressed into the presidency in the (unlikely and tragic) event of a double vacancy.

Section 19 is, at worst, a wash where the democratic principle is concerned. Under a more substantive focus on the electoral constituency actually represented, a cabinet officer, the hand-picked representative of the same national constituency and national policy agenda as the President, is the more democratic choice to become acting president. On the other hand, some may prefer to emphasize the procedural fact of having an acting president who stood for popular election at some level, which concededly has some inherent value. Perhaps this makes legislative succession somewhat more democratic.

However, it is not so much more democratic, in an overall balance, to overcome the substantial political partisanship and separation of powers problems. ${ }^{267}$ Even if the democratic principle individually favors legislative succession in this situation, the balance of the three structural principles still supports cabinet succession as the more consistent approach.

\section{Accommodating Three Principles}

Because cabinet succession is most consistent with both separation of powers and political partisanship, and arguably with democracy, $\S 19$ should be amended to provide that a cabinet officer become acting president in the event of a double vacancy. However, additional accommodations should be made to the democratic principle. Any statute passed under Article II, Section 1, Clause 6 will, after all, place in the White House someone who never stood for election before the national constitu-

${ }^{266}$ We could speculate as to how far this legitimacy would go. Had the 1975 assassination attempt on President Ford succeeded, Rockefeller would have become President and would have had the power to appoint a new Vice President. Query the perceived democratic legitimacy of a Vice President appointed by Rockefeller, a President who had succeeded to the office after being appointed Vice President by Ford, a President who himself had succeeded to the presidency after being appointed Vice President by President Nixon, who had been forced to resign from office.

${ }^{267}$ See discussion supra notes 77-92, 156-70 and accompanying text. 
ency (or before all fifty-one state constituencies) and never won such an election. This specific succeeding officer likely was not on the minds of the individual voters when they cast their votes for any federal office, regardless of whether she had been a member of Congress or the cabinet prior to succession.

The best way to satisfy the democratic principle is to re-establish, as in the original succession statute, procedures for a special election to choose a new President and new Vice President, under established regular Constitutional procedures. ${ }^{268}$ This limits the amount of time under an acting president and provides a President duly and constitutionally elected by the regular national constituency. The chosen President will be better able to establish her own programs and forcefully lead the executive branch, whereas an acting president might see herself more as a custodian of the former President's administration following succession and less able to establish her own agenda. ${ }^{269}$

The President chosen in the special election would serve out only the remainder of the existing presidential term, and the next regular quadrennial presidential election should be held as scheduled. The pattern of federal elections-in which a President is elected every four years and the entire House and one-third of the Senate is elected every two years-is important to the partisan and democratic flow of the political system. The pattern enables voters to consider legislative and executive candidates together every fouryears and to express their approval or disapproval of the President's performance every two years by voting for or against congressional candidates of her party. ${ }^{270}$ It also enables voters to express their desire to keep each party in check by splitting tickets and establishing divided government. ${ }^{271}$ This pattern should remain intact beyond the

${ }^{268}$ See Calabresi, Presidential Succession, supra note 50, at 174 ("The best way to satisfy this democratic concern is, forthrightly, by providing for special presidential elections."); see also A. Amar, Mandates, supra note 29, at 384-85 (emphasizing the importance of the special election provision of the original statute and the need to re-establish that aspect of the succession law).

${ }^{269}$ Cf. UNGER \& UNGER, supra note 89, at 291 (stating that Lyndon Johnson viewed himself as "trustee and custodian" of the Kennedy administration when he first became President and that it took him time to establish his own program).

${ }^{270}$ See Ceaser, supra note 55, at 186 ("'A]though the president holds his term for four years, a new sounding is taken every two years, and a president can lose influence in policy matters if his party suffers a severe setback in the midterm election."); see also discussion supra notes 131-34 and accompanying text.

${ }^{271}$ See discussion supra notes $129-44$ and accompanying text. 
immediate emergency creating the double vacancy and triggering the statute. 272

There is some question as to how quickly this election could or should occur, particularly in the wake of the national tragedy and international crisis that likely created the double vacancy. Commentators suggest anywhere from two to seven months. ${ }^{273}$ Seven months, and perhaps as long as one year, seems more plausible. One cannot imagine gearing up for, and carrying out, a presidential election within sixty days of a September11type terrorist attack that had killed both the President and Vice President. The longer period seems a more realistic time frame in which to stabilize the federal government under the acting president, stabilize the nation, calm and reassure the People of some sense of security, and jump-start the electoral machinery. A special election then becomes unnecessary if one year or less remains on the existing presidential term, since the wheels of the regular quadrennial election are in motion. ${ }^{274}$ The special election also could be held as part of regularly scheduled mid-term elections, if the vacancy occurred during a mid-term election year and that electoral process already is moving forward. ${ }^{275}$

It could be argued that the special election provision renders the acting president a lame duck, limited to a term of only about six to twelve months, such that she would be unable to deal with any immediate crises, particularly in foreign and military affairs. However, any succession statute necessarily seeks a balance among numerous possible scenarios. Holding a special election is more consistent with the democratic principle, in that a President (as opposed to an acting president) will be elected as quickly as possible and someone not elected or ascended to the presidency under the

${ }^{272}$ See Calabresi \& Larsen, supranote 34, at 1093 (describing the "complex and highly sophisticated" three-tiered method for sampling the national will of the people).

${ }^{273}$ Compare Amar \& Amar, Succession, supra note 21, at 138 n.144 (arguing that, allowing time for grieving and campaigning, such an election could not be held for six or seven months), with Calabresi, Presidential Succession, supra note 50, at 174 (arguing for a special election within sixty days).

${ }^{274}$ Compare Amar \& Amar, Succession, supra note 21, at 138 n.144 (arguing that, because the special election could not take place for six months, an acting president should complete the existing term if eighteen months or less remains), with Calabresi, Presidential Succession, supra note 50, at 174 (arguing for a special election whenever one year or more remains on the term).

${ }^{275}$ See Truman, supra note 22, at 130 (suggesting that election for President after double vacancy should be held either during the next congressional election or in special election). 
Constitution will not occupy the White House for a long period of time. Moreover, any concerns for immediate action in foreign policy crises may be addressed by having the Secretary of State or Secretary of Defense, the cabinet officers most familiar and involved with foreign policy, become acting president and serve until the special election chooses a new President.

September 11 illustrates the import of a special election provision in furthering the democratic principle. The Bush administration was less than one year old on September 11. An acting president (Speaker Hastert under the current statute)-someone never even considered by the national electoral constituency-would have controlled the White House for more than three years, until an election in November 2004 and presidential Inauguration in January 2005. On this point, it is irrelevant whether that acting president is the Speaker or the Secretary of State; the problem in terms of the democratic principle arises from the White House being occupied for almost a full presidential term by anyone not elected by the voters of the national constituency according to established procedures.

A special election becomes the only way to respect the democratic principle. It would remove the word "acting" from in front of the name of the person holding the White House, as selection through formal constitutional procedures (as opposed to succession via congressional statute) makes her the President; this is a not insignificant symbolic benefit. More importantly, the election would provide the new President the direct popular imprimatur of the national electoral constituency. ${ }^{276} \mathrm{Her}$ democratic legitimacy in serving the remaining years of the presidential term now derives not from the apostolic legitimacy of her initial selection as a Cabinet officer and power delagatee by the former President, but from the affirmatively expressed will of the national constituency in specifically choosing her for that office.

Importantly, the provision for a special election does not obviate the need for the suggested changes in the succession order. The goal, whenever possible, is the best accommodation of all three structural principles, individually and on balance. Even with a special election, an acting president might serve for as long as a year (if the double vacancy occurs during a quadrennial presidential election year) and at least for several months-not an entirely insubstantial amount of time. The proper official, that is, the officer whose succession is most consistent with these three structural principles, should be the acting president during that time period, no matter how short.

${ }^{276}$ See discussion supra notes $206-21$ and accompanying text. 
It is true that, because an acting president will not simply serve out the multi-year balance of a presidential term, there will be less incentive for a legislative officer to manipulate the political process in order to make herself acting president. ${ }^{277}$ However, the incentives do not disappear. The acting president might have an advantage in any special election, given the benefit of incumbency and the aura of having guided the nation through the tragedy and crisis that created the double vacancy. One could imagine an acting president Powell easily winning a special election held seven months after a September 11 attack that had killed the President and Vice President. Such an outcome would promote democratic and policy continuity in a time of war.

A Speaker willing to gamble that she could win that election (which might be a regular presidential election resulting in a four-year term) running as the incumbent still might give in to the conflicts of interests and negative incentives that exist when a legislator is in the line of succession. ${ }^{278}$ In other words, the special election provision alone does not eliminate political gamesmanship by a legislative officer. The special election must be accompanied by a system of cabinet succession in order to be fully effective.

Alternatively, legislative succession does not fit with a special election. The Speaker or President Pro Tem must, under both the Constitution and the statute, resign her legislative office and seat in order to become acting president. ${ }^{279} \mathrm{~A}$ special election provision makes any double vacancy and the term of an acting president temporary and short-term. This contrasts with the current version of $\S 19$, under which an acting president could serve almost a full presidential term. ${ }^{280}$

After acting as President for six months or so, the Speaker (assuming she did not win the new presidential election) would find herself out of the White House, but also out of her congressional office and seat. ${ }^{281}$ The Speaker, unless willing to gamble that she could win the special election, likely would decline to become acting president by not resigning from Congress and remaining ineligible for the presidency, allowing the executive power to carry into the cabinet. Given this likelihood, it makes

${ }^{277}$ See discussion supra notes 78-84 and accompanying text.

${ }^{278}$ See discussion supra notes 157-62 and accompanying text.

${ }^{279}$ See U.S. CONST. art. I, § 6, cl. 2; 3 U.S.C. § 19(a)(1), (b) (1994).

${ }^{280}$ See discussion supra notes $39-41$ and accompanying text.

${ }^{281} C$ f. Brown \& Cinquegrana, supra note 1, at 1437 (describing the unfairness that anyone who resigned to act as President during a temporary vacancy would be out of a job altogether when the vacancy ended). 
sense simply to remove the legislators entirely from the succession order and send the executive power directly to cabinet officers. ${ }^{282}$

\section{CONCLUSION}

Section 19 is a good illustration of the effect and operation of structural principles and how those principles must be considered, analyzed, and accommodated in designing and operating selection procedures. Congress and President Truman, in drafting and passing $\S 19$, explicitly sought to accommodate two such principles: political partisanship and democracy. Closer examination of these principles shows that they did not do so and that the chosen procedure is not, in fact, the best way to accommodate either one. Moreover, the statute entirely ignores concerns of separation of powers, creating additional problems.

Section 19 and its predecessors never have been triggered, even during those lengthy periods prior to 1967 in which the President served without a Vice President. Often, the statute is brought into the legal and public eye only during odd moments, such as Alexander Haig's infamous press conference in March 1981. It exists primarily for the event of extreme political machinations or extreme and tragic events that might raise concerns not only for the life of the President but also for the continued stability and viability of the federal government and the constitutional structure.

However, we witnessed a potential trigger event on September 11, an attack that may have targeted the highest officers of the federal government. That event and the threat of repeated similar attacks raise the specter of double-vacancy succession to a different level. It warrants reconsideration of $\S 19$ and replacement with the best possible succession order, a scheme that best serves and promotes the guiding principles that dictate selection decisions under the Constitution. Considering those structural principles individually and in an overall balance, the succession order should include only cabinet officers, starting with the Secretary of State, and should provide for a special election to choose a new President and Vice President as expeditiously as possible.

${ }^{282}$ The current version of $\S 19$ requires that cabinet officers also resign upon becoming acting president, raising the same problem. See 3 U.S.C. \$19(d)(3) (providing that "[t] $]$ he taking of the oath of office by [a cabinet officer] shall be held to constitute his resignation" from the cabinet office). However, this is not a constitutional requirement and need not be included in the amended statute. 